\title{
THE DE-MEDICALISATION OF ASSISTED DYING: IS A LESS MEDICALISED
}

\section{MODEL THE WAY FORWARD?}

\author{
SUZANNE OST*
}

\section{INTRODUCTION}

In this paper, I contend that there are current, notable examples of the de-medicalisation of assisted death. Although assisted dying has been most commonly presented within a medicalised framework - a framework revolving around medical concepts and terminology, illnesses and medical professionals - the notion of de-medicalisation is employed to suggest that there are emerging models of assisted dying in which some medical aspects assumed to be an integral part of the phenomenon are both challenged and diminished. Within the social and legal debate surrounding assisted death, the focus in recent times appears to have moved away from a medic's involvement in a clinically assisted death to "suicide tourism" and particularly, the matter of relatives "assisting" by making travel arrangements and accompanying their loved ones to a country in which according to local law, they can receive assistance to die. Debbie Purdy's ultimately successful legal action, swiftly followed by the publication of the DPP's' interim and final policies for cases of assisted suicide and the related public consultation, ${ }^{1}$ have ensured that the matter of relatives facilitating assisted

\footnotetext{
* Law School, Lancaster University. I am grateful to John Coggon for his valuable comments on an earlier draft of this paper. Thanks are also due to Marleen Eijkholt, who kindly provided a translation of the Dutch case discussed in section III. A), and to Hazel Biggs and the two reviewers for the Medical Law Review. Responsibility for any errors remains with the author. This paper is an output of the AHRC funded project, The Impact of the Criminal Process on Health Care Ethics and Practice, see further http://www.law.manchester.ac.uk/research/hccriminalprocess/index.html.

${ }^{1}$ CPS, Interim Policy for Prosecutors in respect of Cases of Assisted Suicide (Crown, London 2009) available at http://www.cps.gov.uk/consultations/as policy.pdf; CPS, Policy for Prosecutors in Respect of Cases of Encouraging or Assisting Suicide (Crown, London 2010) available at http://www.cps.gov.uk/publications/prosecution/assisted suicide policy.html. Information regarding the public consultation on the policy is available at http://www.cps.gov.uk/consultations/as index.html. All web pages last visited 24 March 2010.
} 
suicide abroad (hereafter RFASA) has been kept at the forefront of public consciousness. ${ }^{2}$ One of the focuses of this paper is the development of RFASA and the possible repercussions of de-medicalising the debate surrounding assisted death by focusing on this earlier role in the process of assisted suicide played by non-medics. A further purpose is to address ethical and legal matters that arise when medicine is not the dominant form of reference for assisted death, by considering cases of assisted death that have involved the assistance of a non-medic in the actual suicidal act, and nonmedical grounds for desiring death. Cases of relative assisted suicide (RAS) and mercy-killings carried out by relatives raise significantly different issues than cases of physician assisted death. The same is true for assistance provided by non-medic professionals. Within the jurisdiction of choice for suicide tourism, Switzerland, it most often tends to be volunteer representatives of the Swiss right to die organisation Dignitas who are clergy persons, social workers and nurses assisting in the final act of suicide, rather than doctors. And significantly, the question of whether an individual must be suffering from a medical condition in order for assisted death to be legitimate is increasingly being raised.

Taking into account these key matters, my claim is that we are witnessing something of a demedicalisation of assisted death. However, there has not been and indeed there is not likely to be, a wholesale shift from a medical to a de-medicalised model. In evaluating the potential impact of partial de-medicalisation on the assisted dying debate, I argue that whilst a de-medicalised model could well contribute to a richer understanding of assisted dying and a better death for the person who is assisted, there are cogent reasons to retain some aspects of the medicalised model and that a completely de-medicalised model of assisted dying is unrealistic.

I begin by exploring the terms "medicalisation" and "de-medicalisation" and explicating the way in which I utilise the latter in the context of assisted death. I then present the three matters which I

\footnotetext{
${ }^{2} R$ (on the application of Purdy) v DPP [2009] UKHL 45; [2009] EWCA Civ 92; [2008] EWHC 2565.
} 
suggest provide evidence that the debate surrounding assisted death and the phenomenon of assisted death itself may be moving away from a more medicalised frame of reference. In the final section, I assess the potential positive and negative effects of any such de-medicalisation and consider whether a less medicalised model of assisted death should be the way forward. I should note at the start that the analysis relates primarily to assisted suicide, ${ }^{3}$ although (voluntary) euthanasia ${ }^{4}$ and so-called "mercy killings" ${ }^{5}$ will also be discussed.

\section{MEDICALISATION, DE-MEDICALISATION AND ASSISTED DEATH}

The term medicalisation emerged in the 1970s, through the work of influential authors such as Michael Foucault, ${ }^{6}$ Ivan Illich, ${ }^{7}$ Thomas Szasz ${ }^{8}$ and Irving Zola. ${ }^{9}$ It is a term which has regularly appeared in various fields including sociology, bioethics, anthropology and medicine itself ever since. Conrad defines medicalisation, as 'a process by which nonmedical problems become defined and treated as medical problems'.$^{10}$ Lowenberg and Davis identify a number of ideas that the notion of medicalisation is framed around, including: 'that some undesirable condition or problematic human

\footnotetext{
${ }^{3}$ That is, a suicide assisted by another where the final act is carried out by the person who wishes to die. See also H Biggs, Euthanasia, Death with Dignity and the Law (Hart, Oxford 2001) 60.

${ }^{4}$ For the purposes of this paper, any reference to euthanasia is to the situation where a doctor administers lethal treatment to a patient at his or her request.

${ }^{5}$ I utilise the term "mercy killing" specifically in relation to laypersons who take another's life to bring an end to that other person's suffering. See also R Huxtable, Euthanasia, Ethics and the Law: From Conflict to Compromise (Routledge Cavendish, Abingdon 2007) xv and 8.

${ }^{6} \mathrm{M}$ Foucault, 'The politics of health in the eighteenth century', in C Gordon (ed), Power/Knowledge: Selected Interviews and Other Writings, 1972-1977, (Pantheon, New York 1980) 166; M Foucault, 'Governmentality', in G Burchell, C Gordon and P Miller (eds), The Foucault Effect: Studies in Governmentality, (University of Chicago Press, Chicago 1991) 87; M Foucault, 'The Dangerous Individual', in M Foucault (and LD Kritzman (ed)), Politics, Philosophy, Culture: Interviews and Other Writings of Michael Foucault, 1977-1984 (Routledge, London 1988) 125.

${ }^{7}$ I Illich, Limits to Medicine: Medical Nemesis, the Expropriation of Health (Calder and Boyars, London 1975).

${ }^{8}$ T Szasz, The Medicalization of Everyday Life: Selected Essays (Syracuse University Press, Syracuse NY 2007). See also generally, Nye, 'The Evolution of the Concept of Medicalization in the Late Twentieth Century' (2003) 39(2) Journal of History of the Behavioural Sciences 115.

9 IK Zola, 'Medicine as an institution of social control' (1972) 20(4) Sociological Review 487.

${ }^{10} \mathrm{P}$ Conrad, The Medicalization of Society: On the Transformation of Human Conditions (JHU Press, Baltimore 2007) 4. See also R Moynihan and R Smith, 'Too Much Medicine?' (2002) 324 BMJ 859, 860; N Glover-Thomas and J Fanning, 'Medicalisation: The Role of E-Pharamcies in latrogenic Harm' 18(1) Med L Rev 28, 30.
} 
activity previously lying outside the scope of "the medical model"... has in popular thinking and/or public policy been brought within its purview' and that 'treatment decisions must emanate from and be dispensed by qualified health professionals who, by virtue of their training and expertise, are insofar as treatment is concerned enjoined to stand superior to those they treat. ${ }^{11}$

Theories of medicalisation are concerned with social perceptions and constructions of problems. ${ }^{12}$ Thus, for example, it has been argued that increases in the frequency of diagnosis and treatment of Attention-Deficit Hyperactivity Disorder (ADHD) are partly the result of behavioural problems in children being medicalised and inappropriately diagnosed as ADHD because of parental reaction to media coverage of the condition, social anxieties and the Western conception of self. ${ }^{13}$ Another example of medicalisation is the portrayal of non-medical objects or products as medical. It has been claimed, for instance, that certain food products are promoted as "medicine" through advertising, encouraging the perception that unless we purchase the particular food product, our bodies are more likely to malfunction. ${ }^{14}$

Conversely, de-medicalisation can be defined as 'stripping away medicine as a dominant frame of reference to reveal the "true"' nature of a phenomenon. ${ }^{15}$ Howarth and Leaman refer to the process of de-medicalisation as 'the point at which the medicalisation of social life is turned back, or reversed ${ }^{16}{ }^{16}$ The potential for de-medicalisation is growing in an age in which patients have much easier access to information on the internet about medical conditions, information which once

\footnotetext{
11 JS Lowenberg and F Davis, 'Beyond Medicalisation: the case of holistic health' (1994) 16(5) Sociology of Health and Illness 579, 582. See also N Glover-Thomas's and J Fanning's discussion of two models of medicalisation: professional expansion and systemic permeation. Ibid., 30-34.

${ }^{12}$ See P Conrad, 2007: 4; I Kennedy, The Unmasking of Medicine (Allen and Unwin, London 1981) 7.

13 'Attention-Deficit Hyperactivity Disorder: The Medicalization of Misbehavior' (1998) 5(4) Journal of Clinical Psychology in Medical Settings 467; K Kristjansson, 'Medicalised pupils: the case of ADD/ADHD' (2009) 35(1) Oxford Review of Education 111.

${ }^{14} \mathrm{~S}$ Zwier, 'Medicalisation of food advertising. Nutrition and health claims in magazine food advertisements 1990-2008' (2009) 53(1) Appetite 109. See also the discussion of 'demoralisation syndrome' in section IV.B).

${ }^{15}$ D Lupton, 'Foucault and the Medicalisation Critique', in G Scambler (ed), Medical Sociology: Major Themes in Health and Social Welfare (Taylor and Francis, London 2005) 245, 256.

${ }^{16} \mathrm{G}$ Howarth and O Leaman, Encyclopaedia of Death and Dying (Taylor and Francis, London 2001) 411.
} 
remained within the medical realm. ${ }^{17}$ And de-medicalisation is more likely to occur when patients are empowered and patient rights are championed and prioritised, ${ }^{18}$ as is currently the case in contemporary Western society. No doubt one of the most prominent examples of de-medicalisation is the de-medicalising of normal childbirth in the UK. The 1970s saw the medicalisation of child birth, with a hospital birth being the recommended norm, ${ }^{19}$ but in more recent times, organisations such as the National Childbirth Trust campaign for midwife-led birth centres and encourage women to have natural births and consider giving birth at home. ${ }^{20}$ And during their later years in power, the previous Labour government indicated a preference for a community based midwifery model and woman-focused, family-centred maternity services. ${ }^{21} \mathrm{~A}$ further example of de-medicalisation can be found in the concept of neurodiversity. The neurodiversity movement emerged from within the autistic community in the late $1990 \mathrm{~s}^{22}$ Armstrong explains that neurodiversity's 'basic premise is that atypical neurological wiring is part of the normal spectrum of human differences and is to be tolerated and respected like any other human difference such as race, gender, sexual preference, or cultural background. ${ }^{23}$ Followers of neurodiversity reject the categorisation of autism as an illness that needs curing. ${ }^{24}$

For as long as we have relied on medicine and physicians in our attempts to prolong life and keep death at bay, death and medicalisation have gradually and increasingly gone hand in hand. In

\footnotetext{
${ }^{17}$ See also Nye, 2003: 124.

${ }^{18}$ Moynihan and Smith, 2002: 859; Ibid.: 126-127.

$19 \mathrm{~J}$ Peel, Domiciliary Midwifery and Maternity Bed Needs, Report of the Standing Maternity and Midwifery Advisory Committee (HMSO, London 1970).

20 NCT, The NCT Birth Policy 12 Principles (NCT, London 2002), principles 4 and 5. Available at http://www.nctpregnancyandbabycare.com/about-us/who-we-are/policies. Last visited 26 March 2010.

21 See, for example, 'More women should have babies at home, not in hospital, says Health Secretary', The Independent, 14 May 2006; Department of Health, Maternity Matters: Choice, access and continuity of care in a safe service (Department of Health, London 2007).

22 See T Armstrong, 'Special Education and the Concept of Neurodiversity' (2005). Available at http://www.newhorizons.org/spneeds/inclusion/information/armstrong.htm. Last visited 26 March 2010. ${ }^{23} \mathrm{Ibid}$
}

24 See, for example, K Seidel, 'The Autistic Distinction' (2004), available at http://www.neurodiversity.com/autistic distinction.html. Last visited 26 March 2010. 
the words of lan Kennedy, dying has become an illness. ${ }^{25}$ And death, in many cases, has become a medical event. ${ }^{26}$ Notably, however, medicalised aspects are absent from what Seale and van der Geest have argued is an almost universal notion of a 'good death' ${ }^{27}$ Yet a 2006 survey suggests that only one in three people in the UK will experience a death free from any medical involvement. ${ }^{28}$ Medical intervention at the end of life could involve, for example, the provision and subsequent withdrawal of life-sustaining treatment, or terminal sedation. ${ }^{29}$ One effect of medical intervention to prolong life has been to extend lives which, to those subjectively experiencing these lives, may be lacking in quality. Partly as a consequence of this, but also to offer individuals alternatives to dying in a medical setting, there have been developments in end of life care that mark a move away from a more medicalised death. The palliative care and natural death movements can both be cited as prominent examples of de-medicalisation. ${ }^{30}$ Moreover, campaigns for a "right to die" can be perceived as attempts to prioritise individual autonomy and remove doctors' control over death. ${ }^{31}$

For those who find themselves in such a desperate situation that they decide to end their own lives (whether this is the result of their medical condition or other factors or events in their

\footnotetext{
${ }^{25}$ Kennedy, 1981: 154.

${ }^{26}$ See also AM Capron, 'Legalizing Physician-Assisted Death' (1996) 5 Cambridge Quarterly of Healthcare Ethics $10,11$.

27 'Some ideals about dying well seem nearly universal: a death occurring after a long and successful life, at home, without violence or pain, with the dying person being at peace with his environment and having at least some control over events.' CF Seale and S van der Geest, 'Good and bad death: introduction' (2004) 58 Social Science \& Medicine 883, 385.

${ }^{28}$ See E Jackson, 'Death, Euthanasia and the Medical Profession', in B Brooks-Gordon, F Ebtehaj, J Herring, MH Johnson and M Richards (eds) Death Rights and Rites (Hart, Oxford 2007) 37, 49, citing C Seale 'National Survey of end-of-life decisions made by UK medical practitioners' (2006) 20(1) Palliative Medicine 3. See also D Clark, 'Beyond Hope and Acceptance: the medicalisation of dying' (2002) 324 BMJ 905, 906.

${ }^{29}$ See V Cellarius, 'Terminal Sedation and the "imminence condition"' (2008) 34 JME 69; L Materstvedt and G Bosshard, 'Deep and continuous palliative sedation (terminal sedation): clinical-ethical and philosophical aspects' (2009) 10(6) The Lancet Oncology 622; G Williams, 'The Principle of Double Effect and Terminal Sedation' (2001) 9 Med L Rev 41.

${ }^{30}$ Howarth and Leaman, 2001: 411.

${ }^{31}$ SJ Ziegler, 'Collaborated Death: An Exploration of the Swiss Model of Assisted Suicide for Its Potential to Enhance Oversight and Demedicalize the Dying Process' (2009) Journal of Law, Medicine and Ethics 318, 318; Kennedy, 1981: 158-159.
} 
lives), there are a variety of medical and non-medical means of committing suicide. ${ }^{32}$ However, these methods are only available to those who have the physical ability to make use of them and thus, those who lack this ability are left requiring another person's assistance to die. Significantly, legal, ethical and social discourses surrounding assisted dying and laws that have permitted assisted dying have tended to focus on the assistance of doctors, the provision of medicine to cause death and medical grounds for requesting death, that is, pain and suffering derived from medical conditions. ${ }^{33}$ As such, medicine has provided the main frame of reference, a vital component of the phenomenon of assisted death. The common phrase "physician assisted suicide" (PAS) makes this abundantly clear. Salem argues that PAS:

presupposes that medicine has passed judgment on the act of suicide... as long as the physician is in charge of assisting the patient - either by his or her presence or by supplying the medical means to perform the act - physician-assisted suicide entails the medicalisation of the act of suicide... the decision to die by suicide is treated precisely as if it were a set of clinical problems to be solved medically - the 'private', 'intimate', 'selfdeterminating' decision to commit suicide is translated into a clinical event. ${ }^{34}$

\footnotetext{
${ }^{32}$ See further K Faber-Langendoen and J Karlawish, 'Should Assisted Suicide be Only Physician Assisted?' (2000) 132(6) Annals of Internal Medicine 482, 483.

${ }^{33}$ See D Hillyard and I Dombrink, Dying Right: The Death With Dignity Movement (Routledge, New York 2001), 22-23; Faber-Langendoen and Karlawish, 2000: 482. M Brazier, 'Euthanasia and the Law' (1996) 52(2) British Medical Bulletin 317, 323. Consider the Dutch law (on which, see the discussion in section IV.B), the laws in Belgium (on which see J Griffiths, H Weyers and M Adams, Euthanasia and Law in Europe (Hart, Oxford 2008) part 2) and Oregon (on which see E Jackson, Medical Law: Texts, Cases and Materials (Oxford University Press, Oxford 2010) 916-918; S McLean, Assisted Dying: Reflections on the Need for Law Reform (Routledge, Abingdon 2007) 173-178). Consider also Lord Joffe's Assisted Dying for the Terminally III bill (referred to later, in section III).

${ }^{34}$ T Salem, 'Physician Assisted Suicide: Promoting Autonomy - Or Medicalizing Suicide?' (1999) Hastings Center Report 30, 32 (emphasis in original).
} 
Given that assistance in suicide is requested in order to bring an end to suffering and distress, it is not surprising that the cause of death also tends to be medicalised, and is commonly perceived as such, since medication is considered to offer the quickest, humane non-violent end. ${ }^{35}$

As I will discuss in this paper, however, less medicalised and completely de-medicalised instances of assisted death do occur. A well-publicised example of partially de-medicalised assisted death occurred in Australia in 1996, during the short period in which assisted suicide and euthanasia were lawful in the Northern Territory. ${ }^{36}$ Dr Philip Nitschke devised a process of computerised assisted death. He provided patients with intravenous access and connected the infusion tubing to a laptop computer. The patients then had to answer three questions which appeared on the computer screen by pressing certain keys. The final question was as follows: 'If you press this button, you will receive a lethal injection and die in 15 seconds - Do you wish to proceed?' If the patient answered all the questions affirmatively, the computer automatically switched on a previously prepared solution of a fatal dose of the sedative Nembutal. ${ }^{37}$ The use of modern technology might make this example of partially de-medicalised assisted death seem somehow dehumanised. However, Nitschke stated in an interview that the process 'allowed me to leave the immediate personal space of the patient, so that the family could enter and be closest to the patient when the button was pushed'. ${ }^{38}$ Thus, arguably, far from removing the human element, de-medicalising assisted death in this way can remove the external presence of a medic and enable the act of dying to be a more personal and private experience for the person to share with those she or he is closest to. This is at least one

\footnotetext{
${ }^{35}$ Faber-Langendoen and Karlawish, 2000: 483.

${ }^{36}$ The Rights of the Terminally III Act 1995 was passed by the Legislative Assembly of the Northern Territory in July 1995 and repealed by the Australian Commonwealth Parliament in March 1997. See S Ost, An Analytical Study of the Legal, Moral and Ethical Aspects of the Living Phenomenon of Euthanasia (Edwin Mellen Press, New York 2003), chapter 6; AL Plattner, 'Australia's Northern Territory: The First Jurisdiction to Legislate Voluntary Euthanasia, and the First to Repeal it' (1997) 1(3) DePaul Journal of Health Care Law 645.

37 See KJ Lopez, 'Euthanasia Sets Sail: An interview with Philip Nitschke, the other "Dr Death"', National Review, 5 June 2001. Available at http://www.nationalreview.com/interrogatory/interrogatory060501.shtml. Last visited 26 March 2010. See also Biggs, 2001: 62. ${ }^{38}$ Ibid.
} 
reason that can be given in support of calls for the de-medicalisation of assisted death which have appeared of late in the academic literature. ${ }^{39}$

I am applying the term "de-medicalisation" in the context of assisted death in a number of ways in this paper. First, I utilise it to highlight the way in which attention has moved away somewhat from the medical aspects of assisted death. Concentrating on the role that relatives play in the process of assisted dying by accompanying a loved one abroad may alter perceptions of assisted death as being a wholly medical phenomenon, and encourages the use of a less medicalised discourse which takes emotional factors into greater account. Secondly, I claim that cases where non-medics assist an individual to die raise important questions concerning the basis on which the involvement of a doctor legitimises assisted death. Such cases should cause us to ask why a more medicalised conception of assisted dying is appropriate or inappropriate and therefore, whether demedicalisation is the way forward. Finally, I turn to the common perception that if assisted death is lawful, it should only be available to those whose suffering is the result of a medical condition. If the availability of an assisted death is extended to those experiencing existential suffering, as has been advocated by some, then this could truly amount to a notable form of de-medicalised assisted dying. In addressing these issues, the three areas of medicalisation that I am questioning are: the process of assisted dying; medicalisation of the assistor; medicalisation of the reason for requesting assisted dying.

III. TURNING THE DEBATE SURROUNDING ASSISTED DEATH AWAY FROM MEDICAL ISSUES: THE PHENOMENON OF RFASA

\footnotetext{
${ }^{39}$ See, for example, Faber-Langendoen and Karlawish, 2000; Ziegler, 2009.
} 
Notwithstanding the de-criminalisation of suicide under s.1 of the Suicide Act 1961, encouraging or assisting suicide continues to be an offence under s.2(1) of the same Act. ${ }^{40}$ This has not completely prevented relatives from taking part in assisted suicides, however. ${ }^{41}$ As I will discuss later, there are numerous examples of cases where relatives have assisted in the actual suicidal act (RAS). More recently, there has been a spate of well-publicised cases where relatives have provided help by making travel arrangements and accompanying a person seeking assistance in their suicide to Switzerland, where this act is permitted under certain conditions. ${ }^{42}$ These include the assisted suicides of Reginald Crew (accompanied to Switzerland by his wife and daughter), ${ }^{43}$ Raymond Cutkelvin (accompanied by his partner), ${ }^{44}$ Craig Ewert (accompanied by his wife and whose assisted suicide was filmed and broadcast in a television documentary), ${ }^{45}$ Daniel James (accompanied by his parents), ${ }^{46}$ Dr Anne Turner (accompanied by her three children) ${ }^{47}$ and Elaine Wirr (accompanied by her husband). ${ }^{48}$

Of all of these cases, and others, it is probably the Daniel James case which attracted the most publicity, no doubt because of Mr James' young age (twenty three), the fact that his condition

\footnotetext{
${ }^{40}$ Section 59 of the Coroners and Justice Act 2009 simplified the wording of the 5.2 offence so that it applies to 'an act capable of encouraging or assisting the suicide or attempted suicide of another person' where the defendant intended to encourage or assist.

${ }^{41}$ It has presumably prevented some from assisting. For example, Debbie Purdy claimed she would not allow her husband to assist her unless the current legal position was clarified. 'Debbie Purdy: "We've got our lives back"' The Independent, 31 July 2009. See the later discussion of Debbie Purdy's case in this section.

${ }^{42}$ On which, see the later discussion in section IV.A). See also R Huxtable, 'The Suicide Tourist Trap: Compromise across Boundaries' (2009) 6 Bioethical Inquiry 327.

${ }^{43}$ See 'No charges over assisted suicide', BBC News report, 9 April 2003, available at http://news.bbc.co.uk/1/hi/england/merseyside/2933589.stm. Last visited 26 March 2010.

44 See 'Euthanasia man's partner arrested', BBC News Report, 23 July 2009, available at http://news.bbc.co.uk/1/hi/england/london/8165633.stm. Last visited 26 March 2010.

${ }^{45}$ See 'Professor Craig Ewert's final moments to be broadcast on TV', The Times, 10 December 2008.

${ }^{46}$ See 'Rugby star Dan James in "assisted suicide" after training injury', The Times, 18 October 2008; 'Parents of rugby player in Dignitas assisted suicide will not face charges' The Daily Telegraph, 12 September 2008 and n. 49 below.

47 'By the time you read this, I will be dead', The Daily Telegraph, 25 January 2006; 'Anne Turner sang songs and joked with her children - then she went to a clinic to die', The Independent, 25 January 2006. It should be noted that Anne Turner needed less assistance to commit suicide. Her son stated that 'Our mother was relatively able-bodied when she went off to Switzerland'. See 'A short stay in Switzerland', BBC News Report, 22 January 2009, available at http://news.bbc.co.uk/1/hi/health/7844031.stm. Last visited 26 March 2010.

${ }^{48}$ See 'Why I took my wife to die at Dignitas', The Daily Telegraph, 10 July 2009.
} 
was not terminal and the DPP's subsequent publication of the reasoning behind his decision not to prosecute Daniel's parents. ${ }^{49} \mathrm{Mr}$ James suffered from tetraplegia and was paralysed from the chest down with no independent hand or finger movement following a rugby accident which had occurred a year and a half before his assisted suicide. He decided he no longer wished to live when it became apparent that his condition would not improve and tried to commit suicide three times, unsuccessfully. He then contacted the Swiss right-to-die organisation Dignitas in February 2008. The process of arranging an assisted suicide began ${ }^{50}$ and throughout this time, his parents attempted to change his mind, without success. They eventually accepted his decision, despite their conflicting wishes, and helped facilitate his assisted suicide in Switzerland by making travel arrangements along with a family friend and accompanying him to Switzerland. ${ }^{51}$ Daniel James' assisted suicide took place on 12 September 2008. Following a police investigation, the DPP decided that there was sufficient evidence to prosecute Mr and Mrs James and the family friend for the s.2(1) offence, but he concluded that it was not in the public interest to bring a prosecution..$^{52}$ The DPP emphasised the fact that Mr and Mrs James did not influence their son and that he was 'a mature, intelligent and fiercely independent young man with full capacity to make decisions about his medical treatment'. That they did not stand to gain (financially or otherwise) from their son's death was also an important factor in the DPP's decision. In his view, their actions were 'towards the less culpable end of the spectrum' of acts that were prohibited under $\mathrm{s.2}(1) .{ }^{53}$

For Daniel James and others who need assistance to die, the external power of the law denies them the possibility of an assisted death in their home, local area or indeed, their country of residence and their reaction to the legal prohibition of assisted suicide is to travel elsewhere, with

\footnotetext{
${ }^{49}$ See further Decision of Prosecution - The Death by Suicide of Daniel James, 9 December 2008, available at http://www.cps.gov.uk/news/articles/death by suicide of daniel james/index.html. Last visited 26 March 2010.

${ }^{50}$ On which, see later, section IV.A).

${ }^{51}$ See Decision of Prosecution, above n.49.

52 Ibid. For commentary, see A Mullock, 'Prosecutors Making (Bad) Law?' (2009) 17 Med L Rev 290.

${ }^{53}$ See Decision of Prosecution, above n.49.
} 
the assistance of a relative, in order to experience the kind of death which they seek. Thus, this nonmedical part of the process of assisted dying in such cases is occurring because English law prohibits assisted death. The final act of assisted dying in such cases is, at least in part, a medical one, since death is caused by the ingestion of lethal medication prescribed by a physician in Switzerland. However, the recent focus on the involvement of relatives in the earlier stages of the process of assisted suicide is indicative of a certain de-medicalising of assisted death, because media coverage of assisted death and the attention of the public, prosecutors, law-makers and judges is directed on a non-medical aspect of assisted dying.

Besides drawing attention to the earlier non-medical parts of the process, RFASA cases also emphasise the significance of relatives being present during the final stages of an assisted death. There are a number of reasons why it might be important for individuals seeking an assisted death to have their relatives present for the final act of assisted suicide, and why this could be an essential part of their experience of an assisted death. First, this may make the assisted death feel less medicalised and less clinical and thus, a less tense affair. Secondly, it might reassure the person concerned that their relatives approve of their decision, or at least that they are at peace with their decision to die. Thirdly, they may need the emotional support that their relatives provide. ${ }^{54}$ Their experience of assisted death is therefore a better death because they are accompanied throughout the process by their loved ones. Lesley Close, who accompanied her brother to Switzerland for an assisted suicide through Dignitas, emphasised the significance of his 'chance to say goodbye, to interact with us at that last moment. ${ }^{55}$ According to Dr Turner's son, the family 'chatted, sang some songs and joked' in the final hours before her death. ${ }^{56}$ For relatives, being present at their loved one's death may be equally important so that they can see their wish for an assisted death being

\footnotetext{
${ }^{54}$ I recognise that the first and third of these reasons for having relatives present during the final act of dying would also apply in the context of a 'natural' death, a point to which I will return in the concluding section.

55 'Hewitt Seeks Suicide Law Change', BBC News report, 20 March 2009, http://news.bbc.co.uk/1/hi/health/7954581.stm. Last visited 26 March 2010.

56 'Anne Turner sang songs and joked with her children - then she went to a clinic to die', above n.47.
} 
fulfilled, share their final moments of life with them and ensure that they do not have an isolated death. ${ }^{57}$ They may reaffirm their support for their loved one's decision through their attendance. $\mathrm{Mr}$ Cutkelvin's partner stated: 'I wanted to be with him because this was what he wanted, to die in a dignified and peaceful manner, which is what happened. ${ }^{, 58}$

Whilst in the cases above RFASA had already occurred, the prominent case of Debbie Purdy related to future, intended RFASA. Crucially, Debbie Purdy was not seeking an immunity from prosecution for her husband, Omar Puente. ${ }^{59}$ Rather, her argument revolved around the DPP's exercise of discretion as to whether to bring a prosecution for assisted suicide under s.2(1), laid down by s.2(4) of the 1961 Act. In seeking judicial review of the DPP's refusal to publish a prosecution policy for the s.2(1) offence at her request, she relied on the principle of legality under Article $8(2)$ of the European Convention of Human Rights (ECHR), which requires that state interference with Article 8 rights must be 'in accordance with the law' and thus that the law be accessible and precise in order for individuals to know in advance whether their conduct will be unlawful. ${ }^{60}$ She claimed that Article $8(2)$ demanded clarification in the law in the form of a clear statement of policy from the DPP setting out the factors which will be taken into account in ascertaining whether it is in the public interest to bring a prosecution. Both the High Court and the Court of Appeal judged that her Article 8 rights were not engaged. ${ }^{61}$ This was somewhat inevitable given that both courts were, of course, constrained by the decision of the House of Lords in Pretty $v$

\footnotetext{
${ }^{57}$ BE Chabot and A Goedhart, 'A survey of self-directed dying attended by proxies in the Dutch population' (2009) 68(10) Social Science and Medicine 1745, 1746.

58 'Euthanasia man's partner arrested', above n.44.

${ }^{59}$ Unlike Dianne Pretty. See $R$ (on the application of Pretty) v DPP [2002] 1 AC 800 and later, section IV.A).

${ }^{60}$ See especially paras 40 and 43.

${ }^{61}$ [2008] EWHC 2565; [2009] EWCA Civ 92.
} 
$D P P{ }^{62}$ Both courts also concluded that the DPP's refusal to produce a crime-specific policy did not make the offence relating to assisted suicide not in accordance with law under article $8(2) .{ }^{63}$

However in a unanimous judgment in July 2009, the House of Lords allowed Debbie Purdy's appeal. ${ }^{64}$ Significantly, in departure from the House of Lords' decision in Pretty but in accord with the European Court of Human Rights judgment in Pretty $v U K^{65}$ it was held that Article 8 rights are engaged and interfered with by the prohibition on assisted suicide ${ }^{66}$ and that the DPP was obliged to produce an offence-specific policy pertaining to the approach to prosecution for the s.2(1) offence. ${ }^{67}$ The judges considered both the Code for Crown Prosecutors ${ }^{68}$ and the DPP's publication of his decision in the Daniel James case, ${ }^{69}$ but found that neither provided sufficient guidance as to how prosecutorial discretion is likely to be exercised in cases such as Debbie Purdy's. ${ }^{70}$ As expressed by Lord Hope:

\footnotetext{
${ }^{62}$ See para 47-62 of the Court of Appeal judgment in Purdy. The decisions were also somewhat inevitable given the judiciary's marked conservatism in this area of law, at least until the subsequent House of Lords' judgment in the case.

${ }^{63}$ For the Court of Appeal judges, Mrs Purdy was asking for 'the nearest thing possible to a guarantee that if... her husband assists her suicide when she is no longer able to end her own life by her own unassisted actions, he would not be prosecuted.' But, according to the Court, 'Without giving what in reality would amount either to immunity from prosecution or the promulgation of a policy which would effectively discount the risk of a prosecution in this particular case (which it is accepted cannot be provided) Ms Purdy cannot achieve her true objective.' Para 73 of the judgment (per Lord Judge CJ).

${ }^{64} R$ (on the application of Purdy) v DPP [2009] UKHL 45. See Cartwright's commentary on all of the Purdy judgments: 'Commentary: 48 Years On: is the Suicide Act fit for purpose?' (2009) Med L Rev 467-476.

${ }^{65}$ Pretty v UK (2002) EHRR 1.

${ }^{66}$ See para 34, per Lord Hope and also paras 38 and 39.

67 The House of Lords judges also considered whether assisting another to travel to another country for assisted suicide fell within the ambit of the s.2(1) offence. There was an interesting difference of opinion on this matter. According to Lord Phillips, as s.3(3) of the 1961 Act states that the Act extends only to England and Wales, s.2(1) would seem not to apply to assisting in a suicide that takes place anywhere else and consequently, the assistor would commit the offence of murder (see especially paras 11 and 12). Rejecting contrary academic opinion, Lord Hope concluded that since s.2(1) applies to any of the acts it describes which are performed in this jurisdiction, it does not matter that the final act of suicide occurs elsewhere (see paras 18, 23 and 24 and M Hirst, 'Suicide in Switzerland: Complicity in England?' [2009] Crim LR 335-339). Logically, it would seem that Lord Hope's interpretation of the law is the correct one; it is difficult to believe that having decided assisting a suicide is a serious wrong that should remain an offence, parliament would have intended to remove from the grasp of the criminal law acts of assisting in the suicide process which occur here when the final act of suicide occurs elsewhere.

68 The current version of this was published in 2010 and is available at http://www.cps.gov.uk/publications/docs/code2010english.pdf. Last visited 24 March 2010.

${ }^{69}$ Decision of Prosecution, above n.49.

${ }^{70}$ See paras 53-54, 64, 79-83, $85-86,97$ and 102-3.
} 
In most cases [the Code's] application will ensure predictability and consistency of decision-taking, and people will know where they stand. But that cannot be said of cases where the offence in contemplation is aiding or abetting the suicide of a person who is terminally ill or severely and incurably disabled, who wishes to be helped to travel to a country where assisted suicide is lawful and who, having the capacity to take such a decision, does so freely and with a full understanding of the consequences. There is already an obvious gulf between what section $2(1)$ says and the way that the subsection is being applied in practice in compassionate cases of that kind. ${ }^{71}$

Lord Hope also highlighted the very real possibility that in other cases, factors which did not apply in the Daniel James case might be present, such as the relatives standing to gain a benefit (financial, for example) from the individual's death. Yet such a potential benefit in itself might not mean that prosecution would be in the public interest. ${ }^{72}$ Thus, the DPP's decision in the Daniel James case was specific to its facts and did not clarify the likely position regarding prosecution for others who wished to assist a relative's suicide. There is indeed likely to be a financial benefit in many cases of RFASA and RAS. As Mullock has opined, surely a number of those relatives in RFASA cases such as those mentioned above must have received some kind of financial gain by virtue of inheritance after the assisted suicide, but regardless, none have been prosecuted. ${ }^{73}$ The only conclusion can be that Lord Hope's view is correct; financial gain in itself is not going to lead to a decision that it is in the public interest to prosecute. $^{74}$

\footnotetext{
${ }^{71}$ At para 54 (my emphasis).

${ }^{72}$ At para 53.

73 Mullock, 2009: 297. This is despite the fact that there was a very real concern that when suicide was decriminalised there would be 'imaginable cases of impatiently rapacious heirs and manipulable relatives which was in good measure responsible for the continuation of criminal liability for complicity in another's suicide'. KJM Smith, 'Assisting in Suicide' [1983] Crim LR 579, 586.

${ }^{74}$ Whether a relative assistor would be able to benefit financially from his/her relative's death is a matter that has been considered extensively by J Davey and J Coggon: 'Life Assurance and the Consensual Death: law making for the rationally suicidal' (2006) 65 CLJ 521-548.
} 
In September 2009, the DPP fulfilled the obligation that the House of Lords' judges placed him under, and produced an interim policy regarding cases of assisted suicide for public consultation. ${ }^{75}$ After this consultation, the final policy was published in February $2010 .{ }^{76}$ It is beyond the scope of this paper to engage in a detailed analysis of the policy, but briefly, it outlines public interest factors in favour of prosecution in cases where, amongst other things:

- $\quad$ the victim ${ }^{77}$ was under 18 years of age

- her/his capacity was in question

- s/he 'had not reached a voluntary, clear, settled and informed decision to commit suicide'

- $s /$ he 'had not clearly and unequivocally communicated his or her decision to commit suicide to the suspect'

- the victim did not ask the suspect on her/his own initiative for assistance or encouragement

- the suspect was 'not wholly motivated by compassion' but, for example, was motivated because $s /$ he stood to gain from the victim's death

- 'the suspect pressured the victim to commit suicide'

- 'the victim was physically able to undertake the act that constituted the assistance' herself/himself

- the suspect was acting in her/his capacity as a health care professional, 'or as a person in authority $^{78}$

\footnotetext{
${ }^{75}$ See above, n.1. The consultation period was twelve weeks.

${ }^{76} \mathrm{Ibid}$. For the DPP's response to the public consultation, the summary of responses and an explanation of the differences between the interim and final policies, see CPS, Public Consultation Exercise on the Interim Policy for Prosecutors in respect of Cases of Assisted Suicide (Crown, London 2010) available at http://www.cps.gov.uk/consultations/as responses.pdf. Last visited 24 March 2010.

${ }^{77} \mathrm{As}$ is recognised within the policy, some (including this author) may consider that referring to the individual who commits suicide with assistance as a 'victim' is problematic (CPS, 2010: 1). On a legal level, the status of 'victim' implies that a criminal offence or civil wrong has been committed against the individual. Whilst it is indeed true that the act of assisting suicide amounts to a crime, on a moral level, I seriously doubt that it constitutes a wrong against the individual who wishes to die and seeks assistance in order to do so.

${ }^{78}$ See below, n.196.
} 
- the suspect was acting in her/his capacity as a person involved with an organisation or group that provides a physical environment in which another can commit suicide ${ }^{79}$

Conversely, there are public interest factors tending against prosecution if, amongst other things:

- the victim 'had reached a voluntary, clear, settled and informed decision to commit suicide'

- the suspect was 'wholly motivated by compassion'

- the suspect's actions 'were of only minor encouragement or assistance'

- the suspect's actions could 'be characterised as reluctant encouragement or assistance in the face of' the victim's determined wish to commit suicide ${ }^{80}$

Any one factor can be considered to 'outweigh a number of other factors which tend in the opposite direction ${ }^{81}$ and thus, for example, if there is clear evidence that the suspect was motivated by gain, this might outweigh the existence of several of the public interest factors against prosecution listed above. One potential difficulty here is that this motivation of gain is surely not going to be easy to prove and the mere fact that the assistor stands to gain could exist in many cases, as discussed above. The DPP's policy notes that 'sometimes... the only source of information about the circumstances of the suicide... is the suspect' and advocates a 'common sense approach' to the issue of whether a person stood to gain, emphasising that the 'critical element is the motive behind the suspect's act' ${ }^{82}$ All this is undoubtedly true, but the question remains: what counts as clear evidence of selfish motivation?

\footnotetext{
${ }^{79}$ CPS, 2010: para 43.

${ }^{80}$ Ibid., para 45. For detailed analysis of the policy, see A Mullock's paper in this issue.

81 lbid., para 39.

82 Ibid., paras 41 and 44 . In the first RFASA case in which the final prosecution policy was applied, the CPS concluded that there was no evidence that the son of Sir Edward and Lady Downes was motivated by the financial gain he received upon their deaths: 'The evidence and information available indicates that $\mathrm{Mr}$ Downes was wholly motivated by compassion.' See Statement by Keir Starmer QC regarding the deaths of Sir Edward and Lady Downes, 19 March 2010, available at
} 
Notably, as Lord Brown observed in Purdy, whilst the DPP has produced statements providing details of the policy for prosecution in the case of other offences, such statements have been issued for the benefit of the victims of offences such as rape, rather than for the benefit of prospective offenders. But reliance on the Article 8 rights of individuals who require assistance in their suicides justified the production of a policy statement to effectively assist would-be assistors. ${ }^{83}$ This only serves to emphasise the uniqueness of the legal reaction to cases involving RFASA. It may well have become necessary to produce this policy because Parliament did not envisage the phenomenon of suicide tourism when the s.2(1) offence was drafted. Nonetheless, the result is that the impact of RFASA cases has meant that those who violate the law by assisting a suicide are effectively being treated differently than all other offenders, by being given specific guidance as to the exercise of prosecutorial discretion regarding their criminality. Significantly, therefore, the focus on the non-medical role played by relatives has moved the law on assisted suicide forward.

There was clear judicial sympathy for relatives in Omar Puente's predicament in the Purdy case. Such cases were described as compassionate by more than one of the judges; both Lord Hope and Baroness Hale referred to the actions of relatives who assist a loved one to travel abroad for an assisted suicide as 'compassionate assistance' ${ }^{84}$ In Lord Neuberger's view, RFASA cases are 'difficult and tragic cases where a loving relative assists a person, who is of sound mind and determined to end her life, to travel abroad to achieve her wish in a country where assisting suicide is not unlawful ${ }^{85}$ and he considered that a relative in such a case 'will often be a relatively reluctant

http://www.cps.gov.uk/news/press statements/the death_of sir_edward_and lady downes/. Last visited 26 March 2010.

${ }^{83}$ Above, n.64, para 84.

${ }^{84}$ Ibid., paras 27 and 58. Baroness Hale was quoting Baroness O'Neill in the House of Lords' debate on Lord Falconer's defeated amendment in July 2009, on which, see the discussion in this section below. See para 54 for similar wording, again, from Lord Hope.

${ }^{85}$ Ibid., at para 97. 
participator, and will often be motivated solely by love and/or sympathy'. ${ }^{86}$ Such an understanding of compassionate and reluctant assistance is mirrored in the DPP's policy. ${ }^{87}$

It is surely true that more compassion is likely to be felt for a relative who assists a loved one to die in this way than a health care professional who assists in the final act causing death. Although, as Biggs notes, the euthanasia case of $R v$ Cox 'provoked an emotional response from those who were involved, ${ }^{88}$ it was arguably not so much that the jury and judge felt compassion for the doctor's situation, but rather, that they were sympathetic to his motivation. In contrast, it is easier to feel compassion for a relative assistor because of the dilemma they find themselves in when their loved one asks for their assistance to die, a dilemma which must be exacerbated by the strong attachment they have. Horder has differentiated relatives from other parties involved in assisted dying on the basis that the former act compassionately because they are 'caught in the maelstrom of circumstances' ${ }^{89}$

Given the common shared experience of being in a close, loving relationship, more people can imagine themselves in the position of a relative assistor than a medic assistor. It goes without saying that no one in a loving relationship such as that of Ms Purdy and Mr Puente would wish to be in this predicament. But arguably, if we imagine ourselves faced with the same situation, many of us could understand why relatives decide to assist and no doubt some of us might see ourselves doing the same for our loved ones. In accord with Blum's explanation of compassion, this is a situation where we 'come to understand someone's condition by imagining what our own reactions would be'

\footnotetext{
${ }^{86}$ Ibid., at para 102. Lord Judge CJ expressed the Court of Appeal judges' sympathy 'for the dreadful predicament' which Debbie Purdy and her husband faced. At para 81.

${ }^{87}$ CPS, 2010: para 45(2) and (5).

${ }^{88}$ (1992) 12 BMLR 38. Biggs, 2001: 65.

89 J Horder, 'Some Reflections on Beecham's Case' (1988) Journal of Criminal Law 309, 312. Note also Coggon's reference to RFASA cases as 'a sympathetic act of companionship at a moment of the most profound torment'. J Coggon, 'Assisting 'Death Tourism': Possible Prosecution or Pragmatic Immunity?' (2008) Cardiff Centre for Ethics, Law, and Society (2008), 2. Available at http://www.ccels.cf.ac.uk/archives/issues/2008/index.html. Last visited 26 March 2010.
} 
and emotionally responding to their predicament. ${ }^{90}$ Speaking in an interview about his wife's assisted suicide through Dignitas, Mr Witt commented that 'When you see a loved-one coolly and thoughtfully asking you to do it, I don't see how you can refuse, how you can't show that compassion. ${ }^{91}$ Daniel James' mother emailed the following comment to the Daily Telegraph's website, referring to the person working for social services who had reported her and her husband's actions to the police: 'I hope that one day I will get the chance to speak to this lady and ask if she had a son, daughter, father, mother, who could not walk, had no hand function, was incontinent, and relied upon 24-hour care for every basic need and they had asked her for support, what would she have done ? $^{92}$ This direct question challenges us all to imagine how we would respond in the face of such an awful predicament. Moreover, feeling empathy because one is able to put oneself in the shoes of a relative is more likely in the context of RFASA cases, because of the lesser role played by the relative as compared with a relative who assists in the final act of suicide. Thus, as a consequence of the close, emotional relationship between the person who wishes to die and the relative who facilitates their assisted suicide, RFASA cases encourage a less medicalised discourse surrounding assisted death, one that is more emotive and empathetic.

The spate of RFASA cases has had a definite impact on the legislature. Both Patricia Hewitt's and Lord Falconer's recent unsuccessful attempts to bring about legal reform by amending the Coroner's and Justice Bill 2009 were directed to decriminalising the act of assisting a relative or friend to go abroad and seek assisted suicide. ${ }^{93}$ Notwithstanding the focus on the actions of non-

\footnotetext{
${ }^{90}$ L Blum, 'Compassion', in A Oksenberg Rorty (ed), Explaining Emotions (University of California Press, Los Angeles 1980), 507, 509 and 510. See also B Carr, 'Pity and Compassion as Social Virtues' (1999) 74(3) Philosophy 411, who refers to compassion as involving 'a shared experience of suffering' (at 411).

91 'Why I took my wife to die at Dignitas', above, n.48. Consider also the comments of Anne Turner's son, Edward Turner in 'Clinic assists doctor's suicide', BBC News Report, 24 January 2006, available at http://news.bbc.co.uk/1/hi/health/4625538.stm. Last visited 26 March 2010.

92 'Why Daniel James chose to die', The Times, 19 October 2008; 'Mother defends rugby suicide son', BBC News Report, 18 October 2008, available at http://news.bbc.co.uk/2/hi/uk news/england/hereford/worcs/7677706.stm. Last visited 26 March 2010.

93 'Hewitt Seeking Suicide Law Change', BBC News report, 20 March 2009, http://news.bbc.co.uk/1/hi/uk politics/7953570.stm; 'Hewitt Leads Call to Protect Suicide Helpers', The Independent, 20 March 2009. Hewitt's amendment was not voted on. In contrast to the proposals from
} 
medic assistors, the proposed process under Lord Falconer's amendment would still have involved medical professionals since, in order for RFASA to fall outside the criminal law, it would have been necessary for two doctors to certify that the individual was suffering from a terminal illness and had the capacity to request assisted suicide. ${ }^{94}$ The amendment was defeated (194 peers were against it and 141 were in favour of it). ${ }^{95}$ Clearly, the amendment's defeat does not mark the end of the matter. Last year, for instance, a Labour MP expressed his intention to bring a private member's bill before the House of Commons in the near future to ensure that the legal position on assisted suicide is debated. ${ }^{96}$

Centring proposals for law reform on de-criminalising RFASA cases means that the controversial medical issues of public trust in the medical profession and of assisted death being against ethical principles that the medical profession abides by are not crucial obstacles that must be overcome, as they are when proposed reforms related to physician assisted death. Rather, these issues are left for the country in which assisted suicide is lawfully practised. However, as I will later argue, any reform which does relate to RFASA cases may pave the way for future reform that could relate to PAS and thus, to a re-medicalisation of the debate. That permitting RFASA was the first step on a slippery slope to legalising assisted dying was certainly a concern for some of the peers who participated in the House of Laws debate on Lord Falconer's amendment. ${ }^{97}$

In sum here, RFASA cases pose significantly different issues than more medicalised cases of assisted dying such as Cox for example. The issue of feeling compassion for the assistor enters into

Patricia Hewitt and Lord Falconer, the failed Assisted Dying for the Terminally III Bill (the most recent version of which was presented in 2005), was framed around medicalised assisted death, since it would have permitted health care professionals to assist a "qualifying patient" to die. See clauses 1 and 8 of the Assisted Dying for the Terminally III Bill 2005, available at http://www.publications.parliament.uk/pa/ld200506/ldbills/036/2006036.pdf. Last visited 26 March 2010.

${ }_{94}$ Hansard, HL Deb, 7 July 2009: column 597.

${ }^{95}$ Hansard, HL Deb, 7 July 2009: column 634.

${ }^{96}$ See 'Government may consider assisted suicide bill', The Daily Telegraph, 4 August 2009 and the reference to Lord Alderdice's failed amendment in the final section of this paper.

${ }^{97}$ Hansard, HL Deb, 7 July 2009: columns 606, 611-612, 614, 620, 622 and 625. 
the social and legal debate regarding RFASA cases much more; there is a real sense of empathy with the predicament that relatives face. This seems to be at least part of the reason why prosecutions have not been brought in the case of relatives who accompany an individual abroad for an assisted death ${ }^{98}$ and why the matter of prosecution and possible law reform has become a particular concern for the judiciary and legislature of late. Whether this means that legal reform should be framed around such cases of de-medicalisation is a different matter, which I will consider in the final section.

\section{THE PHENOMENON OF ASSISTED DYING AS LESS OF A MEDICAL ISSUE}

\section{A. Mercy killings, RAS cases and the involvement of (professional) non-medics in the final act of}

\section{assisted death}

The prominence of the phenomenon of RFASA may well have turned the social and legal debates regarding assisted suicide away from a more medicalised framework. But there are, of course, also a number of well-publicised cases where relatives have assisted in the final act of suicide or carried out a mercy killing which have occurred in the UK over the past few decades. ${ }^{99}$ And RAS and mercy killing cases are not just phenomena occurring in the UK. ${ }^{100}$ To give just one example of a recent

\footnotetext{
98 See also H Biggs, 'Criminalising Carers: Death Desires and Assisted Dying Outlaws', in B Brooks-Gordon, F Ebtehaj, J Herring, MH Johnson and M Richards (eds) Death Rights and Rites (Hart, Oxford 2007) 58, 64.

99 For just a few examples, see “"Loving son” kills parents', BBC News report, 4 April 2003, available at http://news.bbc.co.uk/1/hi/england/2916731.stm; 'Assisted suicide man walks free', BBC News report, 19 October 2006, available at http://news.bbc.co.uk/1/hi/england/southern counties/6065836.stm; 'Mercy killing husband spared jail', BBC News Report, 2 September 2005, available at http://news.bbc.co.uk/1/hi/england/somerset/4209296.stm; Horder, 1988. All web pages last visited 26 March 2010. A large number of RAS and mercy killing cases have been discussed by Huxtable. See Huxtable, 2007: chapters 2 and 3. See also S Ost, 'Euthanasia and the Defence of Necessity: advocating a more appropriate legal response' in C. A. Erin and S. Ost (eds) The Criminal Justice System and Health Care (Oxford University Press, Oxford 2007) 99, 105-9.

${ }^{100}$ It is interesting to note that even in a jurisdiction where certain instances of assisted death are lawful, RAS does occur. Although only physician assisted death is lawful in the Netherlands, quantitative research indicates that cases of assisted death do occur where someone other than a doctor has prepared the drugs for the individual to take (B Chabot, Auto-euthanasie: verborgen stervenswegen in gesprek met naasten (Uitgeverij Bert Bakker, Amsterdam 2007). Referred to in J Griffiths et al, 2008: 182-184. When RAS does occur, it must
} 
much-publicised British case, in 2008, Kay Gilderdale administered morphine to her thirty one year old daughter who was paralysed and unable to swallow due to the condition of ME, which she had been suffering from since the age of fourteen. Although Mrs Gilderdale pleaded guilty to aiding and abetting her daughter Lynn's suicide, the DPP pursued a charge of attempted murder since he considered that the evidence suggested that she went further than assisting and directly took her daughter's life. Mrs Gilderdale was found not guilty by a jury who reached a unanimous verdict after less than two hours deliberation. She was released with a one year conditional discharge. The trial judge's criticism of the attempted murder charge and sympathy towards Kay Gilderdale was notable. 101

Medicine is not the dominant form of reference which reveals the true nature of assisted death in RAS cases. Again, as in cases of RFASA, the relationship of love and affection is a significant factor which generates empathy for the relative who assists in a severely ill person's suicide, a factor which is not present in a more medicalised assisted death, where the assistor is a physician. The relative's act is almost seen as an act of love, albeit an unlawful one. For example, in a 2006 case where a husband pleaded guilty to the offence of aiding and abetting his wife's suicide, Judge Brian Barker emphasised that the defendant was 'a husband who not only had a deep love for his wife but who displayed a selfless devotion to her. ${ }^{102}$ A further distinction between RAS and mercy killing cases on the one hand, and physician assisted death on the other, is that a relative is likely to find it

be because the parties involved have decided not to involve a physician for whatever reason, or physicians have been approached and concluded that criteria for lawful assisted death by physician would not be met (see also Chabot and Goedhart, 2009: 1746 and 1750). Significantly, then, these Dutch cases evidence a demedicalisation of assisted dying, since such instances of assisted suicide do not meet the requirements of the (lawful) medical model.

${ }^{101}$ See 'Devoted mother Kay Gilderdale should never have been prosecuted, says judge', The Times, 26 January 2010; 'Why was Kay Gilderdale in court charged with attempted murder?', The Daily Telegraph, 26 January 2010. Following the jury's verdict, Mr Justice Bean stated: ‘I do not normally comment on the verdicts of juries but in this case their decision, if I may say so, shows that common sense, decency and humanity which makes jury trials so important in a case of this kind... There is no dispute that you were a caring and loving mother and that you considered that you were acting in the best interests of your daughter.' See 'Mother cleared of ME daughter's attempted murder', BBC News Report, 25 January 2010, available at http://news.bbc.co.uk/1/hi/england/sussex/8479211.stm. Last visited 26 March 2010.

${ }^{102}$ See 'Assisted Suicide man walks free', above n.99. 
much harder to resist fulfilling their loved one's wish that their suffering be brought to an end. Examining the case of those who take on the role of informal carer for an individual suffering from a chronic condition and provide assistance with that individual's suicide (most often a relative or spouse), Biggs considers the impact of the close relationship between the carer and the cared for person: 'Not only does this make informal carers vulnerable to pressures that professional carers might reasonably be expected to resist, it can also generate a sense of obligation that will encourage a carer to comply with the will of the cared for person. ${ }^{103}$ Yet Biggs argues that if carers assist and criminal culpability is established, the law will draw little distinction between them or a health care professional who assists. ${ }^{104}$ In the context of relatives and spouses who carry out mercy killings and are charged with murder, however, I have suggested elsewhere that the availability of the defence of diminished responsibility to reduce the charge to one of voluntary manslaughter means that such defendants can be treated more leniently by the law than physicians who carry out euthanasia. ${ }^{105} \mathrm{It}$ also seems that the judiciary tends to carry this leniency through to the sentencing stage. ${ }^{106}$

The defence of diminished responsibility is currently available in mercy killing cases if the defendant was suffering from an abnormality of mental functioning arising from a recognised medical condition which substantially impaired the defendant's ability to do one or more of the following: understand the nature of her/his conduct; form a rational judgement; exercise selfcontrol). The abnormality of mental functioning must have been a significant contributory factor in causing him/her to act. ${ }^{107}$ Given the accepted reliance on this defence in such cases, it is here that the legal response evidences a clear medicalised approach to otherwise non-medicalised instances of assisted death. Psychiatric experts play a considerable role in determining whether the defence of diminished responsibility will be available, since it is their assessment as to whether the mercy killer

\footnotetext{
103 Biggs, 2007: 59.

104 Ibid.

${ }^{105}$ S Ost, 2007: 105-9. See also Huxtable, 2007: chapter 2.

${ }^{106}$ See Huxtable, 2007: 48.

${ }^{107}$ S.2(1) of the Homicide Act 1957, as reformulated by section 52 of the Coroners and Justice Act 2009.
} 
was suffering from an "abnormality of the mind" which counts. But Huxtable has persuasively argued that abnormality of the mind can be inferred by psychiatrists even where the mercy killer is "mentally normal", and that it is easy for stress to be labelled as a medical condition. ${ }^{108}$ This raises the question of whether there is a legal fudge going on here; medicalisation through the practical operation of the diminished responsibility defence makes the mercy killer's actions more excusable at law, even when the reality is that there may be no medical cause for his or her actions. It would seem that the desire to treat mercy killers with compassion can be fulfilled if a medical explanation for their behaviour can be found. Medicalisation of the mercy killer's behaviour thus provides this sympathetic legal response with a cloak of respectability.

Turning back to RAS, the most prominent case which would have involved such an assisted death if the applicant had been successful in her legal battle is that of Dianne Pretty. The declaration that Mrs Pretty sought - that s.2(1) of the Suicide Act 1961 was incompatible with various Articles under the ECHR - and the facts of the case are well-known. ${ }^{109}$ For the purposes of this paper, I wish to focus on the reason why the European Court of Human Rights reached the conclusion that the violation of Mrs Pretty's right to personal autonomy under Article 8 of the ECHR was justifiable. The Court drew attention to the need to protect 'the weak and vulnerable and especially those who are not in a condition to take informed decisions against acts intended to end life or to assist in ending life. ${ }^{\prime 110}$ This particular concern is arguably greater if there is no objective, external involvement in the assisted suicide. Taking advantage of vulnerability is easier if the person in question is under the relative's sole care twenty four hours a day and the motivation to act in this way could exist if there will be some (financial) gain for the relative following the person's death. This is something to bear

\footnotetext{
108 Huxtable 2007: 39-41.

${ }^{109}$ For academic commentary and analysis, see H Biggs, 'A Pretty Fine Line: Life, Death, Autonomy and Letting it B' (2003) 11(3) Feminist Legal Studies 291; M Freeman, 'Denying Death its Dominion: Thoughts on the Dianne Pretty Case' (2002) 10(3) Med L Rev 245; B Hale, 'A Pretty Pass: When is There a Right to Die?' (2003) 32(1) CLWR 1; Huxtable 2007: 79-82; A Pedain, 'The Human Rights Dimension of the Diane Pretty Case' (2003) 62(1) CLJ 181.

${ }^{110}$ Pretty v UK (2002) EHRR 1. Per Mr M Pellonpää, President of the European Court of Human Rights, para 74.
} 
in mind regarding a number of the public interest factors in favour of prosecution as stated in the DPP's prosecution policy. It may be easier for a relative to pressure on the victim, for example, without detection. If objective involvement from someone other than relative/carer is considered preferable to better protect the vulnerable, the crucial question which I will address in the final concluding section is whether this has to be the involvement of a physician. Lord Bingham emphasised the fact that Dianne Pretty's assisted suicide was likely to be a non-medicalised one in the House of Lords' judgment in Pretty: '[The DPP] received no information at all concerning the means proposed for ending Mrs Pretty's life. No medical supervision was proposed. ${ }^{, 111}$ Notably, this may evidence an assumption that external involvement in an assisted death should come from a doctor and thus, an acceptance of the dominant medical model of assisted death. As I will argue later, this need not be the case.

Whilst RAS and mercy killings are forms of assisted dying that clearly lack a medical dimension, they do not necessarily indicate that assisted suicide is becoming de-medicalised. Those who are assisted in their death by relatives or friends could not have received PAS under the law in this jurisdiction, and thus their positions have not become de-medicalised; they were never medicalised in the first place. However, in Switzerland, a different form of lawful non-medic assisted death has attracted legal and social attention which may be more indicative of a move towards partial de-medicalisation, because it is a newer phenomenon occurring as part of a process which also involves a doctor. Assisted suicide is a criminal offence under Article 115 of the Swiss Penal Code if carried out for reasons of self interest. ${ }^{112}$ The context in which assisted suicide is lawful as a

\footnotetext{
${ }^{111} R$ (on the application of Pretty) v DPP [2002] 1 AC 800, per Lord Bingham at 826. See also Lord Hobhouse's judgment, 851-852.

${ }^{112}$ G Bosshard, 'Switzerland' in Griffiths et al, 2008: 463, 470. Significantly, reform of the Swiss legal position is on the horizon. The Swiss federal government is concerned about "suicide tourism" and wishes to ensure that assisted dying should only be used as a last resort. A bill will be introduced into Parliament following a public consultation which ended on 1 March 2010. Two legislative proposals were published for consultation, one which will impose stricter regulations on assisted dying, such as the need for the individual's condition being incurable and likely to be fatal within months, for the opinion of two medical professionals on this matter and for more detailed written records from the right-to-die organisation. The other proposal would ban assisted
} 
consequence of Article 115's limited prohibition is of significant note. Crucially, there is no medicalised construction of the circumstances in which assisted death can be permissible; provided there is no selfish motivation, and the person being assisted is competent, ${ }^{113}$ anyone can assist. A physician's involvement is required, however, since Pentobarbital, the drug used in cases of assisted suicide, is only available on prescription. ${ }^{114}$ The physician who prescribes the drug must assess the individual's competency and his/her medical condition. ${ }^{115}$ But this tends to be the extent of the physician's role, as it is most often a volunteer from a right-to-die organisation who provides vital assistance by, for example, collecting the prescription and storing it, mixing the drug and giving it to the person for the actual act of suicide (the last step in this final act must be taken by the individual who wishes to die), ${ }^{116}$ besides making an initial assessment of the individual. Volunteers of the rightto-die organisations are often clergypersons, social workers or nurses who will receive training in matters such as counselling. ${ }^{117}$ Significantly, then, this form of non-medic assisted death tends to involve professional non-medics.

In the early 1980s, two right-to-die organisations were founded in the French and German speaking areas of Switzerland, Exit Association pour le Droit de Mourir dans la Dignité and Exit Deutsche Schweiz. Dignitas, one of the two right-to-die organisations that accept non-residents, was

dying completely. See "'Death tourism" leads Swiss to consider ban on assisted suicide', The Guardian, 28 October 2009; 'Swiss crackdown on "suicide tourism" could spell end of Dignitas clinic', The Times, 29 October 2009; 'Switzerland plans new controls on assisted suicide', BBC News Report, 2 July 2010, available at http://news.bbc.co.uk/1/hi/england/sussex/8479211.stm. http://www.bbc.co.uk/news/10461894. Last visited 3 July 2010.

${ }^{113}$ The latter being an implicit condition. See Bosshard, 2008: 471-472; SA Hurst and A Mauron, 'Assisted suicide and euthanasia in Switzerland: allowing a role for non-physicians' (2003) 326 BMJ 271, 271.

${ }^{114}$ Although Dignitas has been trialling assisted suicide by a non-drug method which would remove physicians' prescribing role. See RD Ogden, WK Hamilton and C Whitcher, 'Assisted suicide by oxygen deprivation with helium at a Swiss right-to-die organisation' (2010) 36 JME 174.

${ }^{115}$ Bosshard, 2008: 472-3; G Bosshard, E Ulrich, SJ Ziegler and W Bar, 'Assessment of Requests for Assisted Suicdei by a Swiss Right-To-Die Society' (2008) 32 Death Studies 646, 653.

${ }^{116}$ Bosshard, 2008: 479; Ziegler, 2009: 322; S Fischer, CA Huber, L Imhof, R Mahrer Imhof, M Furter, SJ Ziegler and G Bosshard, 'Suicide assisted by two Swiss right-to-die organisations' (2008) 34 JME 810.

${ }^{117}$ Bosshard, 2008: 474; Bosshard et al, 2008: 647. 
founded in $1998 .{ }^{118}$ The four right-to-die organisations provide assistance to individuals throughout the assisted suicide process. For Dignitas, this process involves a number of steps:

1. The individual requesting an assisted suicide must become a member of the organisation.

2. S/he must send a letter to Dignitas stating the reason for requesting an assisted suicide, accompanied by a medical file/report regarding diagnosis, prognosis etc.

3. There is an initial assessment of whether Dignitas' guidelines are satisfied (the individual must be suffering from a fatal disease or have an unacceptable disability). ${ }^{119}$

4. Dignitas finds one of their collaborating Swiss physicians who will state an initial willingness to write a prescription (usually about two and a half months after the initial request).

5. An appointment with this physician is made and the physician conducts a detailed medical assessment of the individual. A period of around two months is usual between this and the next step. ${ }^{120}$

6. A volunteer from Dignitas is present and assists during the final part of the assisted suicide process. Before the final act, the individual is asked again whether s/he still wishes to die and a declaration of suicide is signed.

7. The individual takes anti-vomiting medication, followed by Pentobarbital about half an hour later.

8. A representative of Dignitas informs the police that an assisted suicide has occurred. ${ }^{121}$

118 See LA Minelli, 'DIGNITAS in Switzerland' (2007) 3. Available at http://www.dignitas.ch/WeitereTexte/FriendsAtTheEnd.pdf. Last visited 26 March 2010. The other right-to-die organisation which accepts non-residents is Exit International.

119 Bosshard, 2008: 471.

${ }^{120}$ Although it has been alleged by a former senior member of staff at Dignitas, Soraya Wernli, that 'Some foreigners - Germans and English - would come to Zurich in the morning, be taken to the doctor and by midafternoon they were dead.' See 'Murky truth behind Swiss suicide "clinic" Dignitas', The Times, 25 October 2008.

${ }^{121}$ Minelli, 2007. 
According to the results of a survey published in 2003, in 92 per cent of cases where a doctor was involved in the assisted suicide process, a right-to-die organisation was also involved. ${ }^{122}$ This indicates that the majority of assisted suicides occurring in Switzerland (excluding RAS cases) are assisted by professional non-medics. Those occurring with the assistance of right-to-die organisations in the case of Swiss residents often take place in the resident's own home and consequently can be seen to de-medicalise assisted death to an even greater extent because 'the home can once again become the location of death, freed from invasive medical procedures and regarded as a natural event rather than a medical one that occurs at some remote institution staffed by strangers. ${ }^{123}$

To consider the occurrence of non-medic assisted death in another jurisdiction, whilst in the Netherlands assisted death carried out by non-medics remains unlawful, ${ }^{124}$ such assistance does occur and prosecutions have resulted. ${ }^{125}$ A recent example of assistance from a member of a rightto-die organisation can be found in a decision of the District Court in Almelo, pronounced in May 2009. ${ }^{126}$ The Court found Gerard Schellekens, the president of a Dutch right-to-die organisation, guilty of the offence of assisted suicide ${ }^{127}$ and he was sentenced to ten months imprisonment. He had assisted an eighty year old woman suffering from Parkinson's Disease by providing her children with Pentobarbital, which she then took herself. The Court judged Schellekens to have assisted as a non-medic and emphasised that the Dutch legislation evidenced the legislature's intention that assisted suicide should only be lawful in cases in which there would be medical supervision of the

\footnotetext{
${ }^{122}$ Bosshard, 2008: 476. Bosshard estimates that approximately 0.5 per cent of all deaths in Switzerland are assisted suicides (at 477).

${ }^{123}$ Ziegler, 2009: 325.

${ }^{124}$ See the discussion in the next sub-section.

${ }^{125}$ Griffiths, Weyers and Adams, 2008: 184.

$126 \quad$ LJN: BI5890, Rechtbank Almelo, 08/750709-07. See zoeken.rechtspraak.nl/resultpage.aspx?snelzoeken=true\&searchtype=ljn\&ljn=BI5890\&u linn=BI5890. Last visited26 March 2010. Translation provided by Marleen Eijkholt.

${ }^{127}$ Under article 294 of the Dutch Penal Code. Schellekens is currently appealing against the sentence imposed. See 'Hoger beroep Gerard Schellekens', Mag lk Dood? blog, 21 June 2009, available at http://weblogs.hollanddoc.nl/magikdood/2009/06/21/hoger-beroep-gerard-schellekens/. Last visited 7 April 2010.
} 
process and procedure, and where a doctor's decision would be scrutinised afterwards. ${ }^{128}$ In this particular case, the doctor treating the woman had refused to assist her suicide. The Court stated that it would only be in truly exceptional, catastrophic circumstances such those of war, where there were no doctors available, that a non-medic's act of assisted suicide or euthanasia could be lawfully excused. This judgment provides a clear illustration of the way in which Dutch law is wholly imbued by the medical model of assisted death; assisted dying can only be legitimate if performed by a doctor within a medicalised framework, as will be further demonstrated in the next section. Whether Dutch society is only prepared to accept medicalised assisted death is another matter, however. One interesting point made in the judgment in this case is that for many Dutch people, the current law does not go far enough and that what Schellekens did in this case might be a way of acting that they approve of.

\title{
B. The matter of whether "pain and suffering" as a criterion for lawful assisted death should be extended to suffering where the cause is non-medical
}

\begin{abstract}
It is not for society to tell people what to value about their own lives. But it may be justifiable for society to insist that we value their lives even if they do not... The House, when debating Lord Falconer's amendment, was clearly concerned that some of the people who had made use of the services of Dignitas in Switzerland were not suffering from terminal or seriously debilitating diseases... a relevant question must be in what circumstances the law is justified in interfering with a genuinely autonomous choice. ${ }^{129}$
\end{abstract}

\footnotetext{
128 Since November 1998, Regional Review Committees review reported cases of euthanasia and have provided further elucidation of the due care criteria that physicians must comply with under Dutch law. If the Committee decides that the physician involved has not complied with the law, then only at this stage do the prosecution authorities becomes involved. See Griffiths, Weyers and Adams, 2008: 85-90.

${ }^{129}$ Baroness Hale in $R$ (on the application of Purdy) $v$ DPP, above, n.64, para 68.
} 
The phenomenon of assisted dying will always retain a significant medicalised aspect whilst there is a requirement that suffering stems from a medical condition in order for an assisted death to be (perceived as) legitimate. Furthermore, as Baroness Hale's statement in Purdy above indicates, legislation or proposed legislation permitting the practice of assisted dying tends to be limited to cases where individuals' suffering is caused by terminal or incurable medical conditions. ${ }^{130}$ Although respect for autonomy is one of the main grounds relied on by proponents of assisted death, it seems that autonomy in this context has limits imposed on it. But should it only be the autonomy of an individual suffering as a result of a medical condition that is respected? As Huxtable and Möller observe, "Suffering" itself is not a medical term and obviously, although "illness" is a significant cause thereof, it by no means commands a monopoly. ${ }^{131}$ If compassion and the desire to act in accordance with an individual's autonomy are the main grounds for allowing assisted death, and we accept that existential suffering can subjectively be as unbearable as suffering caused by a medical condition, then it is hard to defend permitting assisted death only in cases where suffering stems from medical condition. Furthermore, if there is no treatment available to lessen existential suffering, it could be less bearable than some forms of physical and psychiatric illnesses which can be treated.

In the Netherlands, the legal basis for allowing assisted death exists under the Termination of Life on Request and Assisted Suicide (Review Procedures) Act of 2002, which effectively ratified existing legal practice. Doctors can lawfully carry out euthanasia or an assisted suicide provided they comply with the due care criteria laid down in the Act. The criteria includes, amongst other things, that: the patient's request be 'voluntary and carefully considered'; her suffering is 'unbearable' and

\footnotetext{
${ }^{130}$ Consider Lord Joffe's Assisted Dying for the Terminally III Bill, the Dutch law and Oregon's Death with Dignity Act, for example. On the latter, see Ziegler, 2009: 320-322. Although there is no requirement under Swiss law that the person requiring assistance suffers from a medical condition (at least at this moment in time - see above, n.112), the existence of a medical condition is a pre-requisite for the practice of assisted suicide through right-to-die organisations. See Bosshard, 2008: 471.

${ }^{131}$ R Huxtable and M Möller, 'Setting a Principled Boundary'? Euthanasia as a Response to "Life Fatigue'”' (2007) 21(3) Bioethics 117, 121. See also McLean, 2007180.
} 
there is no prospect of improvement in her condition; that both doctor and patient are convinced there is no reasonable alternative and the doctor has consulted an independent physician. ${ }^{132}$ The doctor must notify the municipal pathologist as required by the Law on Burial and Cremation. ${ }^{133}$ The due care criteria has been interpreted as requiring a medical condition which has led to the person desiring euthanasia or assisted suicide. This interpretation was put to the test by the Brongersma case in 2000-2003.

A District Court in Haarlem first heard the case in 2000. The defendant, Doctor Sutorius, was alleged to have assisted Mr Brongersma in his suicide. Mr Brongersma no longer had any desire to live a life he considered futile and lonely without his deceased friends and family and had consequently made repeated requests to Doctor Sutorius to assist him in his suicide. $\mathrm{Mr}$ Brongersma's suffering had no somatic cause, nor was it the result of any psychiatric illness. The central question for the court was whether this suffering could be described as unbearable, in accordance with the due care criteria. Was it legitimate to end Mr Brongersma's life to relieve unbearable existential suffering? An independent psychiatrist gave evidence in court that there was no treatment which could alleviate Mr Brongersma's suffering. The court also heard from an ethicist, who stated his opinion that Mr Brongersma's suffering could be perceived to be unbearable, brought about by a state of hopelessness from which only death would provide any relief. The District Court judged that the doctor had acted in accordance with the due care criteria and acquitted Sutorius. An appeal was then made to the Court of Appeal in Amsterdam on the ground of whether the unbearable suffering criteria would extend to a situation where a patient wishes to die because he feels that his life is futile and utterly hopeless. The Court of Appeal held that the existential suffering could not be described as unbearable under the due care criteria. Whilst Sutorius was convicted of assisting his patient's suicide, the Court of Appeal chose not to pass any

\footnotetext{
${ }^{132}$ See further Griffiths et al, 2008: 84.

${ }^{133}$ Ibid., 126-7.
} 
sentence upon him because of the compassionate motivation behind his act. ${ }^{134}$ In 2003, in the final judgment in the case, the Supreme Court affirmed the Court of Appeal's judgment, holding that a physician who ends life in such circumstances acts outside of his professional duty. ${ }^{135}$ The Supreme Court differentiated between suffering caused by a medical ailment (whether mental or physical), and psychological suffering. When a case involved the latter, a doctor's medical expertise did not equip him or her to decide whether the due care criteria had been met. ${ }^{136}$

The limitation of the due care criteria to unbearable suffering caused by a medical condition has been critiqued by Griffiths, Weyers and Adams. Citing empirical evidence regarding the views of the Dutch population ${ }^{137}$ and the report of the Dijkhuis Committee, a Committee appointed by the Royal Dutch Medical Association in support of their case, they argue that the distinction drawn between suffering derived from medical conditions and existential suffering is hard to defend and problematic in practice. ${ }^{138}$ Indeed, Huxtable and Möller contend that "Once "life fatigue" is understood as a form of suffering, we have no logical warrant for debarring euthanasia as a response thereto. ${ }^{139}$ It is thus notable that recent research indicates that in cases where a request for physician assisted dying is refused, patients consider that the doctor did not understand their suffering and that patients place much more emphasis on psychosocial suffering whereas their

\footnotetext{
${ }^{134}$ See T Sheldon, “'Existential” Suffering not a Justification for Euthanasia' (2001) 323 BMJ 1384.

${ }^{135}$ Nederlandse Jurisprudentie 2003, no.167.

${ }^{136}$ See http://archives.tcm.ie/breakingnews/2002/12/24/story81954.asp. Last visited 15 March 2010.

137 Significantly, a citizens' initiative, 'Out of Free Will', has recently collected over 100,000 signatures in support of its campaign for legal reform to permit specially trained non-medical staff (including nurses and psychologists) to assist individuals aged over 70 who wish to die because they are tired of life. It seems that the matter will now be debated by the Dutch Parliament. See 'Dutch plan to let healthy elderly people commit suicide', Daily Telegraph, 10 March 2010; “"Right to die" for elderly back at centre of Dutch debate', NRC International, 9 February 2010, available at http://www.rnw.nl/english/print/59439. Last visited 15 March 2010.

${ }^{138}$ KNMG, Op zoek naar normen voor het handelen van artsen bij vragen om hulp bij levensbeëindiging in geval van lijden aan het leven: verslag van de werkzaamheden van een commissie onder voorzitterschap van prof. J Dijkhaus (KNMG, Utrecht 2004); Griffiths, Weyers and Adams, 2008: 35-38, and at 49-50.

${ }^{139}$ Huxtable and Möller, 2007: 121-122.
} 
doctors are more likely to concentrate on physical suffering. ${ }^{140}$ But ascertaining the nature and extent of non-medical suffering is a highly subjective task, and conclusions as to whether such suffering is 'unbearable' could vary in each individual case. Thus, a potential danger of loosening the medical criteria for assisted death is that it becomes harder to identify and maintain boundaries. ${ }^{141}$ That being said, it may actually be no more of a subjective task than ascertaining the level of pain caused by medical conditions, since it is a well known fact that everyone has different pain thresholds. ${ }^{142} \mathrm{~A}$ further related danger is that in extending the criteria to non-medically based suffering, society risks encouraging an assisted dying culture, with an assisted death being seen as an option whenever life becomes especially taxing or difficult. ${ }^{143}$ And related to this concern, we might ask whether assistance should really be provided if the person is not prevented from ending their own life by a medical condition. The answer here may differ depending on whether the person before us is an able-bodied person, or a person who is increasingly immobile not because of a medical condition, but simply because of old age. Moreover, the answer may also depend on the level of assistance that is required to enable the individual to avail himself/herself of the best possible death (for example, providing a lethal prescription of drugs may be necessary to facilitate this, whereas administering a lethal injection may not). Such questions and concerns explain the tendency of calls for the legalisation of some form of assisted death to be limited to cases where unbearable or intolerable suffering is of a medical origin.

Perhaps extending permissible assisted death to cases of existential suffering is also problematic because of problems of defining such suffering, beyond being able to say that it is

\footnotetext{
${ }^{140}$ HRW Pasman, ML Rurup, DL Williams and BD Onwuteaka-Philpsen, 'Concept of unbearable suffering in context of ungranted requests for euthanasia: qualitative interviews with patients and physicians' (2009) 339 BMJ b4362.

${ }^{141}$ There is, therefore, a policy reason for justifying what appears to be an arbitrary distinction; we might accept that existential pain and suffering could be as unbearable as suffering deriving from a medical condition, but maintain that a line should be drawn between the two because this better safeguards against abuse. This is a similar line of approach to that adopted by the European Court of Human Rights in Pretty $v$ UK when considering Article 8(2) of the ECHR (at para 74).

${ }^{142}$ See Capron, 1996: 22.

${ }^{143}$ Huxtable and Möller, 2007, 124.
} 
caused by social rather than medical factors. It has been suggested that individuals can become so "weary of life" that they wish to die because of "circumstances such as the loss of a partner, increasing isolation due to death of people around them, and physical ailments [which] can make everyday life... a negative experience' ${ }^{144}$ But confusion is caused by the existence of a more medicalised notion of existential pain. Strang et al argue that there is no uniform definition of "existential pain", but rather, there are varying ideas that it is constituted by existential suffering and/or pain as it is physically understood. ${ }^{145}$ The results of their study involving chaplains, palliative physicians and pain specialists revealed that:

The hospital chaplains of this study defined [existential pain] exclusively as existential suffering, with an emphasis on existential guilt and unresolved religious questions. The palliative care physicians focused on issue of meaning and death anxiety, which can amplify the suffering from pain and which definitely reduce quality of life regardless of whether pain is present. The pain specialists emphasized the pain of living, with never-ending suffering, particularly in relation to chronic pain. ${ }^{146}$

Further blurring of the boundaries between existential suffering and pain caused by a medical condition emerge because of the concept of "total pain" in palliative care, which encompasses 'physical symptoms [of an illness], mental distress, social problems and spiritual needs'. ${ }^{147}$ And being "tired of life" can be a reason for desiring an assisted death for individuals who have a severe

\footnotetext{
${ }^{144}$ ML Rurup, MT Muller, BD Onwuteaka-Philipsen, A van der Heide, G van der Wal and PJ van der Maas, 'Requests for euthanasia or physician-assisted suicide from older people who do not have a severe disease: an interview study' (2005) 35 Psychological Medicine 665, 670. See also AF Jorm, AS Henderson, R Scott, AE Korten, H Christensen and AJ Mackinnon, 'Factors Associated with the Wish to Die in Elderly People' (1995) 24 Age and Ageing 389. It is clear from Rurup et al's study that the desire for a physician assisted suicide because of existential suffering can be persistent. See Rurup et al, 669.

${ }^{145}$ P Strang, S Strang, R Hultborn and S Arnér, 'Existential Pain - An Entity, a Provocation, or a Challenge?' (2004) 27(3) Journal of Pain and Symptom Management 241, 243.

146 Ibid., 247.

${ }^{147}$ Strang et al, 2004: 242. The concept was first proposed by Dame Cicely Saunders. See C Richmond, 'Dame Cicely Saunders' (2005) 331 BMJ 238.
} 
disease, just as it can for those who do not. ${ }^{148}$ This is important, since it indicates that even in cases where individuals meet the common medical model of assisted death, they do not request assisted dying wholly for medical reasons. ${ }^{149}$ Moreover, 'the domain of medicine is hopelessly ill defined, such that it cannot easily be objected that "life fatigue" falls outside its perimeters. ${ }^{150}$ Consider here the proposed psychiatric disorder of "demoralisation syndrome" (DS). ${ }^{151}$ Parker explains that according to palliative care health professionals who have proposed DS, for its sufferers:

The future is perceived as hopeless from a present state of pessimism, helplessness, loss of purpose and meaning and entrapment. There may be associated social isolation but this too is not essential to the diagnosis. Researchers cite evidence of other associations, including old age, disfigurement, disability, dependency, concern about being a burden on others, fear of loss of dignity and importantly, a desire for death. ${ }^{152}$

A range of potential forms of treatment for DS, including cognitive behaviour therapy, have been suggested. ${ }^{153}$ Such moves to medicalise existential suffering can only increase the potential for uncertainty as to whether such suffering has, or must have, a medical basis.

Public opinion in the UK on whether non-medical suffering should be a valid ground for requesting an assisted death is not easy to gauge. However, the results of a British Social Attitudes

\footnotetext{
${ }^{148}$ See ML Rurup, BD Onwuteaka-Philipsen, MC Jansen-van der Weide and G van der Wal, 'When Being "Tired of Living" plays an important role in a request for euthanasia or physician -assisted suicide' (2005) 74 Health Policy 157 (hereafter Rurup et al, 2005b), 160.

149 '[P]eople with severe diseases do not usually request [physician assisted death] exclusively for medical reasons, but also because of the complex psychological effects of their medical condition and its consequences.' Ibid., 165.

${ }^{150}$ Huxtable and Möller, 2007: 123.

${ }^{151}$ D Kissane, D Clarke and A Street, 'Demoralization syndrome - a relevant psychiatric diagnosis for palliative care' (2001) 17 Journal of Palliative Care 12; D Clarke, D Kissane, 'Demoralisation: its phenomenology and importance' (2002) 36 Australian and New Zealand Journal of Psychiatry 733; DW Kissane, 'The Contribution of Demoralization to End of Life Decisionmaking' (2004) 34(4) Hastings Center Report 21.

152 M Parker, 'Medicalizing meaning: demoralization syndrome and the desire to die' (2004) 38(10) Australian and New Zealand Journal of Psychiatry 765, 766. 153 Ibid.
} 
survey in 2005 suggest that only a minority would support the occurrence of assisted death in such a situation. ${ }^{154}$ Participants were asked whether they would support a change in the law to permit assisted dying in questions framed around a medicalised presentation of reasons for requesting assisted death. ${ }^{155}$ They were asked for their opinion in a situation where (i) an individual has a terminal, incurable and painful illness, or (ii) an incurable, painful but non-terminal illness, or (iii) is 'not in much pain nor in danger of death, but becomes permanently and completely dependent on relatives for all their needs'. ${ }^{156}$ There was a strong level of support for legal change in respect of the first situation (four out of five people), which decreased to 45 per cent in the second situation and 43 per cent in the third. As the lowest number of participants supported lawful assisted dying where an individual's medical condition is not terminal or incurable, it is not unreasonable to surmise that this number would have decreased again if they had been presented with a case where the suffering was existential.

It is undeniably more controversial to advocate assisted death when the cause of the suffering is non-medical. But is this in fact a consequence of the power of the medical model of assisted death? Have we become so imbued by medicalisation that the idea that suffering which originates from a non-medical cause could be unbearable is automatically rejected as fallacious? And because assisted death is so commonly placed within a medical framework, does this not promote the perception that its practice can only be controlled if it remains within the confines of the medical domain?

\footnotetext{
${ }^{154}$ E Clery, S McLean and M Phillips, 'Quickening death: the euthanasia debate', in NatCen, British Social Attitudes: The $23^{\text {rd }}$ Report - Perspectives on a changing society, (Sage, London 2007) 35.

${ }^{155}$ 'We presented respondents... with descriptions of patients with different conditions, a number of which were incurable or terminal... The public acceptability of voluntary euthanasia clearly depends on how ill someone is.' Ibid., 38-39 (my emphasis).

${ }^{156}$ Ibid, 39.
} 


\section{CONCLUDING THOUGHTS: IS DE-MEDICALISING ASSISTED DYING A POSITIVE OR NEGATIVE}

\section{WAY FORWARD?}

In the final part of this paper, I wish to address the pros and cons of de-medicalising assisted death in the ways I have suggested are occurring. First, the phenomenon of RFASA has fuelled the debate as to whether assisted dying should be de-criminalised. In 2008, 69 per cent of 2,000 members of the public who participated in a poll conducted for the Sunday Times supported a change in the law so that relatives in RFASA cases are given immunity from prosecution. ${ }^{157}$ Moreover, RFASA cases also reveal the importance of non-medicalised parts of the assisted dying process: the presence and support of relatives during the process as part of the individual's subjective experience of a "good" assisted death, and of relatives' subjective experiences regarding their loved one's assisted death. There is perhaps even room for the argument that relatives' experiences could and should play a role in shaping our understanding of the phenomenon of assisted death, if we are searching for less medicalised conceptions of assisted dying. ${ }^{158}$ Although this could be objected to on the basis that a presentation of assisted dying incorporating relatives' experiences would be too emotional, we cannot escape the fact that death and assisted dying are emotional matters and a failure to take due account of this means that we are not seeing the true nature of the phenomenon. But whether a demedicalised model of assisted dying in which relatives are the assistors should be the way forward is a very different matter - the strong emotional attachment clearly raises the issue of objectivity. Furthermore, if those who assist are in a close familial relationship with the assisted person, it is

\footnotetext{
157 'Public in strong backing for right to assisted suicide', Sunday Times, 14 December 2008. More recently, a YouGov poll carried out for the Daily Telegraph revealed that 80 per cent of participants did not wish to see relatives who assist in a loved one's suicide prosecuted. See 'Assisted suicide: 4 in 5 say do not prosecute', Daily Telegraph, 31 January 2010.

158 See phenomenological research studies in other contexts, such as B Brown, J Barnes, M Clarke et al, 'Relatives' lived experiences of complementary therapies in a critical care department - a phenomenological study' (1999) 12(4) Australian Critical Care 147; C Wallengren, K Segesten and F Friberg, 'Struggling for freedom-lived experiences of being a relative of a stroke survivor in the first six months after hospital discharge' (2008) 3(4) International Journal of Qualitative Studies on Health and Well-Being, 230; AJ Walters, 'The lifeworld of relatives of critically ill patients: A phenomenological hermeneutic study' (2007) 1(1) International Journal of Nursing Practice 18.
} 
easier for any vulnerability of the latter to be taken advantage of. Factors that cause prosecution to be in the public interest according to the DPP's policy, such as a non-compassionate motivation and pressure, will be harder to discover if there is no external involvement in the assisted dying process. For these and other reasons presented below, the model of assisted death this paper advocates is a partially de-medicalised one, involving external assistors.

Although the DPP's policy provides no guarantee of immunity from prosecution and 'each case must be considered on its own facts and on its own merits', ${ }^{159}$ it provides general guidance as to the public interest factors for and against prosecution in cases of assisted suicide. Effectively, the publication of this policy, as demanded by the House of Lords in Purdy, has done no more than maintain the status quo, albeit that the reasons for this status quo have now been made clear to the public. ${ }^{160}$ But the publication of the DPP's statement of policy may well mean that relatives who accompany an individual abroad for an assisted death no longer have to 'run the gauntlet of the criminal law before they can discover whether or not compassion will be exercised' ${ }^{161}$ Moreover, the presentation of the circumstances in which relatives should have little fear of prosecution is likely to make the process of assisted dying a better, less clinical experience for some individuals who seek an assisted suicide abroad. An interview with a woman suffering from multiple sclerosis who planned to go to Switzerland for an assisted death was shown during a BBC News report in July 2009. She explained how she has not told her carers and friends because she feared that anyone accompanying her would be prosecuted. She poignantly stated that without this threat: 'I wouldn't have to go alone. I wouldn't have to die alone.'162

\footnotetext{
${ }^{159}$ CPS, 2010: paras 39 and 47.

${ }^{160}$ Although MPs who have signed an Early Day Motion laid in the House of Commons on 1 December 2009 were of the view that that the policy has done more than maintain the status quo, considering that it has overridden the will of Parliament and put 'the vulnerable at grave risk'. See CPS, 2010: para 1.15.

${ }^{161}$ Biggs, 2007: 71. And it provides clarity for those who plan to assist a loved one's suicide in cases of RAS and all other assisted suicide cases. The DPP's policy applies to any act of assisted suicide, whether the final act occurs within this jurisdiction or abroad. See CPS, 2010: para 8.

162 'Change in Assisted Dying Law Rejected', BBC News report, 7 July 2009, http://news.bbc.co.uk/1/hi/health/8139621.stm. Last visited 26 March 2010.
} 
By explicating the public interest arguments against prosecution of assistors in cases of assisted suicide, does the DPP's policy not assist proponents of the legislation of assisted death? Is it not incongruous that we now have clearly stated public interest factors against prosecuting assistors in RFASA cases, at least in part for reasons of compassion, yet individuals who wish to die and those who accompany them are forced to go abroad to receive medical assistance to die? Could this be first step on a path that will lead to the eventual de-criminalisation of assisted dying? ${ }^{163}$ If so, the demedicalisation of the debate surrounding assisted suicide may ultimately strengthen the case for lifting the prohibition on (probably medicalised) assisted death. ${ }^{164}$ There remains a large chasm between maintaining the legal prohibition on assisted suicide whilst publishing public interest factors against prosecution, and de-criminalising assisted suicide. However, when taken with the results of the polls referred to above, the publication of the DPP's policy can only draw attention to the marked discrepancy between on the one hand, the law on assisted suicide as laid down in statute and on the other, the law as applied in practice and public opinion. At the very least, high profile cases involving the matters of RFASA and RAS such as Purdy and the Gilderdale case ensure that assisted death and the moral legitimacy of the current legal position continue to be significant matters for public debate. ${ }^{165}$ In Purdy, Lord Brown presented a scenario involving:

a loved one, in desperate and deteriorating circumstances, who regards the future with dread and has made a fully informed, voluntary and fixed decision to die, needing another's compassionate help and support to accomplish that end... is assistance in those circumstances necessarily to be deprecated? Are there not cases in which... many might regard such conduct as if anything to be commended rather than condemned? In short, as it seems to me, there will on occasion be situations where... it would be possible to regard

\footnotetext{
${ }^{163}$ See also R Huxtable and K Forbes, 'New interim guidance on assisted suicide' (2009) 339 BMJ 1209, 1210.

${ }^{164}$ Although, as Huxtable notes, 'allowing assisted suicide tourism need not mark the first step in the direction of allowing assisted suicide back home'. Huxtable 2009: 334.

${ }^{165}$ See also Coggon, 2008: 13.
} 
the conduct of the aider and abettor as altruistic rather than criminal, conduct rather to be understood out of respect for an intending suicide's rights under article 8 than discouraged so as to safeguard the right to life of others under article $2 .{ }^{166}$

Whilst Lord Brown then swiftly emphasised that he was not expressing a view as to whether the law should be altered, ${ }^{167}$ the fact that a Law Lord was at least prepared to challenge the basis of the prohibition on assisted death in cases of suicides assisted by a relative should not go unnoticed.

Notwithstanding the recent proposals which would have decriminalised the act of assisting a relative or friend to go abroad and seek assisted suicide discussed earlier, proposals for legal reform to permit assisted dying and laws under which assisted death is lawful under certain conditions tend to relate to medicalised, physician-assisted death. ${ }^{168}$ At the heart of the Assisted Dying for the Terminally III Bill, ${ }^{169}$ for example, there lay 'an assumption that the safest and most effective method of organising the regulation of assisted suicide is to ensure that it is conducted by health care professionals. ${ }^{170}$ Critics of medical power challenge assumptions that a phenomenon can only be regulated effectively by doctors. In Salem's view, for instance, 'it is not (or not only) the need for technical expertise that impels us to physician-assisted suicide. Rather, our culture, so impregnated by medicalisation, takes for granted that assisted suicide should fall under the control and supervision of medicine. ${ }^{171}$ It is the idea of our taking for granted the need for medical control over assisted dying that needs to be addressed, and one way we can do this is to consider the case for and against involving doctors in assisted dying.

\footnotetext{
${ }^{166}$ At para 83 (emphasis in original).

167 Ibid.

168 See also Hurst and Mauron, 2003.

${ }^{169}$ See above, n.93.

${ }^{170}$ Biggs, 2007: 68.

${ }^{171}$ Salem, 1999: 33 (emphasis in original).
} 
It is important to bear in mind that the medical profession does not appear to be keen to be involved in legalised assisted dying. A survey completed by 3733 medical professionals in 2007-2008 revealed that the majority were not in favour of legalising euthanasia or PAS. ${ }^{172}$ This position is supported by a vote taken regarding whether to support calls to legalise assisted death for patients who are 'terminally ill and have mental capacity' at a BMA conference held in July $2009 .{ }^{173}$ Undoubtedly, it is the principle of non-maleficence that lies at the heart of the profession's reluctance to assist in facilitating and causing a patient's death. ${ }^{174}$ It is thus of note that Capron has suggested that the role of the doctor in an assisted death could be reduced to simply providing the prescription, so that 'the physician is actually under less of a psychological or a moral impediment to acting. ${ }^{175}$ But if the main motivation behind permitting assisted death is one of compassion, then arguably, the final act causing death should involve a doctor. Medicalised assisted death or euthanasia is the better option because doctors are better able to deal with the situation if things go wrong. ${ }^{176}$ Will a non-medic assistor be equipped to deal with situation where, for example, the individual vomits back the drugs? ${ }^{177}$ Bosshard refers to a Swiss case in which two individuals who wished to die were still alive (in a coma) several hours after they had taken the lethal drug and an Exit volunteer suffocated them both with a plastic bag. ${ }^{178}$ To be able to deal with such eventualities, however, the assistor in the final act does not necessarily have to be a doctor, but could instead be a specially trained nurse. Indeed, in the context of the Swiss model of assisted death, it has been

\footnotetext{
${ }^{172}$ C Seale, 'Legalisation of euthanasia or physician-assisted suicide: survey of doctors' attitudes' (2009) 23 Palliative Medicine 205, 209.

173 'Doctors oppose legal protection for assisted suicide relatives' The Guardian, 1 July 2009. BMA members who voted were 'overwhelmingly' against such legal reform. See 'RCN neutral on assisted suicide', BBC News Report, 25 July 2009, available at http://news.bbc.co.uk/1/hi/health/8167454.stm. Last visited 26 March 2010; D Cohen, 'BMA Meeting: Doctors vote against protecting relatives who accompany people abroad for help with dying' (2009) 339 BMJ 2699. A similar position appears to be taken by the medical profession in the United States - see Faber-Langendoen and Karlawish, 2000: 482.

${ }^{174}$ D Sullivan, 'Euthanasia versus letting die: Christian decision-making in terminal patients' (2005) 21(2) Ethics and Medicine 109; Hurst and Mauron, 2003: 273. For a contrasting view, see S Woien, 'Life, Death, and Harm: Staying within the Boundaries of Nonmaleficence' (2008) 8(11) American Journal of Bioethics 31.

${ }^{175}$ Capron, 1996: 17.

${ }^{176}$ E Jackson, 2007: 41; Faber-Langendoen and Karlawish, 2000: 484.

${ }^{177}$ I suggest that the means of causing death be lethal drugs because although there are non-medical means of causing death, as stated in section II, medication is considered to offer the quickest, non-violent end.

178 Bosshard, 2008: 475.
} 
contended that where the volunteer is a nurse who has special training and experience, the final part of the assisted suicide process may be safer than if assistance were provided by a GP who has no specialist training and has not assisted in a suicide before. ${ }^{179}$

Whilst an appropriately trained nurse could well fulfil this role at the end of the assisted dying process, the involvement of a medical professional at an earlier stage in the process remains necessary to make assessments that require medical expertise, such as whether any mental condition might be impairing a person's capacity. As I will argue below, non-medical concerns relating to the individual's free will can be assessed by someone without medical expertise, but evaluating certain aspects of capacity such as impairment of cognition requires psychiatric knowledge. ${ }^{180}$ Moreover, to convince those who are wary of legal reform to permit assisted dying because of concerns about ensuring that it is the free will of the person that $s /$ he wishes to die, involving a doctor to evaluate the psychiatric aspects of capacity will in all likelihood have to be an essential requirement of any law permitting assisted death. Indeed, when Lord Alderdice sought to add a clause to the Coroners and Justice Bill 2009 (now Act) in the House of Lords which would have permitted assisted suicide where a coroner investigated the circumstances and was satisfied that it was the 'free and settled wish' of the individual to die, the coroner's involvement in this matter was immediately rejected by other peers. ${ }^{181}$ Looking to the Swiss model again, as already noted, a doctor must conclude that a person is competent. This is also a matter ascertained (separately) by the volunteer from the right-to-die organisation. In cases where it is ascertained that depression affects an individual's capacity for decision-making, the right-to-die organisation will not provide

\footnotetext{
179 Bosshard, 2008: 478-9. Or note Brazier's suggestion that the role could be taken on by a 'licensed thanatologist'. Brazier, 1996: 322.

${ }^{180}$ Parallels can be drawn here with the importance of medical expertise regarding psychiatric aspects of capacity in the context of ascertaining testamentary capacity for executing a will. See KI Shulman, I Hull and CA Cohen, 'Testamentary Capacity and Suicide: an overview of legal and psychiatric issues' (2003) 26 International Journal of Law and Psychiatry 403. I note that it is not a legal requirement regarding testimonial capacity that capacity be medically evaluated.

${ }^{181}$ See the views expressed by Baroness Butler-Sloss and Lord Patten, Hansard, HL Deb, 26 October 2009: columns 1080 and 1082.
} 
assistance. $^{182}$ It is of concern that volunteers of right-to-die organisations with no medical professional background and expertise are making decisions regarding the impact of depression on decisional capacity. ${ }^{183}$ Although a physician's assessment is also required under the Swiss model, at the very least, this raises questions about the appropriateness of the role of non-medics regarding this significant matter. ${ }^{184}$

Such concerns should lead to a rejection of Capron's suggestion that the doctor's role in assisted dying be limited to just providing the prescription. However, there are still good reasons for advocating some degree of de-medicalisation, such as the following: first, de-medicalisation could offer a better opportunity for those who wish to have an assisted death to die at home surrounded by their loved ones. This does raise the issue of whether, if assisted dying becomes lawful, demedicalisation along these lines would privilege those receiving an assisted death above those who die naturally. Should we divert significant funds to make death a "cosier" affair for the former, but not the latter? As a matter of justice, this would clearly seem unfair. Before taking forward partial de-medicalisation in the form of enabling an assisted death to occur in the home, it would thus be necessary to assess whether death in this environment could also be offered to patients in hospitals or hospices, for example, whose deaths are not assisted and to consider what is realistically achievable in a publically funded healthcare system. Secondly, partial de-medicalisation could mean that the professional involved in ascertaining non-medical competency issues is someone familiar to the person, who s/he has known and trusted for long period of time (a clergyperson or spiritual adviser, for example). Thirdly, de-medicalisation addresses the fact that a large proportion of the medical profession see PAS as violating the principle of non-maleficence and fourthly, a predominantly medicalised assisted death can be perceived in a negative light, as increasing medical

\footnotetext{
${ }^{182}$ Bosshard et al, 2008: 647.

${ }^{183}$ Ibid., 654-655.

${ }^{184}$ Cf Minelli's view in Select Committee on Assisted Dying for the Terminally III Bill, Minutes of Evidence Examination of Witnesses, Visit of a Delegation of the Select Committee on Assisted Dying for the Terminally III Bill to DIGNITAS, Switzerland (Questions 2325a - 2397), 3 February 2005, 9. Available at http://www.dignitas.ch/media dignitas/Visit to Dignitas.pdf. Last visited 26 March 2010.
} 
professionals' power over life and death. Notably, according to the qualitative analysis undertaken in Seale's study involving a 2007-2008 survey of medical professionals, some of those participants who were in favour of assisted dying qualified their support by 'expressing concern about medical involvement, to the extent that some argued for a specialisation in assisted dying that might not involve doctors. ${ }^{185}$ There may thus be some support within the medical profession for a more demedicalised model of assisted death.

One way of partially de-medicalising the 'ascertaining competency' stage of the assisted dying process would be to adopt a legal model under which the non-medical concerns relating to the individual's free will are assessed by other professional parties. As Faber-Langendoen and Karlawish contend, ${ }^{186}$ matters such as coercion, family dynamics and emotional and economic pressures do not require medical expertise, and could be addressed by social workers, nurses, clergypersons or other spiritual advisors. ${ }^{187}$ The physician's role would then be limited to ascertaining the medical aspects of competency. The Swiss model does adopt such an approach by involving the representative from the right-to-die organisation in making assessments as to decision-making capacity. However, it is arguable that given the nature of the organisation, the assistor may lack objectivity regarding the request for assisted suicide. Significantly, in their study of the way in which assisted suicide requests were dealt with by Exit, Bosshard et al state: 'we do not know how much the Exit Staff members were able to maintain the neutrality required for an objective assessment rather than succumbing to over-identification with the applicant's particular point of view. ${ }^{188}$ This may always be a concern

\footnotetext{
${ }^{185} 176$ medical professionals provided qualitative comments regarding a policy to permit medically assisted dying. 31 per cent were in favour of such a policy and 27 per cent of these participants stated that there was a need for non-medics to carry out assisted death. Seale, 2009: 208-209. There is evidence to suggest that a significant proportion of members of the medical profession are not in favour of a change in the law to provide immunity to relatives in RFASA cases. At the same BMA conference referred to above, 52 per cent of BMA members opposed calls to revise the law so that cases of RFASA are exempted from prosecution. 'Doctors oppose legal protection for assisted suicide relatives', above, n.173. 44 per cent did not oppose such legal reform.

${ }^{186}$ Faber-Langendoen and Karlawish, 2000: 484.

${ }^{187}$ See also Bosshard, 2008: 480; Capron, 1996: 15.

${ }^{188}$ Bosshard et al, 2009: 655.
} 
when the non-medic playing a role in the assisted dying process is from a right-to-die organisation. Conversely, if lack of objectivity is an issue, we might ask why we should trust doctors to behave more impartially than anyone else? Some doctors will be pro-assisted dying, some will be against. Would we choose not to trust the judgement of doctors who support assisted dying just because of their personal views? At least in the case of volunteers from right-to-die organisations, their personal views are known and provided checks regarding the procedure of assisted dying are in place, this should not pose a threat to the safety of the process.

Related to this latter point, a final further reason for advocating a fuller role in the assisted dying process for the medical professional could be to ensure adequate review of the assisted dying process, whether this is prospective or retrospective review, and to better guarantee public accountability. ${ }^{189}$ However, this could again be ensured by the involvement of a professional nonmedic who is accountable for their actions to a professional regulatory body, and by ensuring there are proper checks and controls throughout the assisted dying process. It is significant that whether the assistor is a doctor, a non-medic professional or a relative, a relationship of trust is an important common denominator in all cases of assisted death. Those whose death is assisted trust that their assistors will fulfil their wishes and act in their interests rather than in self interest. The matter of public trust is also important - the public must trust those given the responsibility of assisting death to do so only in appropriate cases. ${ }^{190}$ This suggests that any professional person involved should belong to a profession in which the public are willing to place their trust.

In essence then, if a partially de-medicalised model of assisted death is perceived to be desirable, the way forward could be a less medicalised, team based approach to assisted death. This could involve a doctor who would deal with the medical aspects of an individual's competency,

\footnotetext{
${ }^{189}$ See also Salem, 1999: 32.

190 This could well be the reason why the members of the public who took part in the British Social Attitudes survey in 2005 were less likely to support RAS than assisted dying involving a doctor. See Cleary et al, $2007: 42$.
} 
confirm that any requirements regarding the existence of and nature of a medical condition are met and ensure that alternative treatment options had been explored. A non-medic professional familiar to the patient could then step in to address non-medical aspects of competency and to provide a supportive role throughout the remainder of the process, and a specially trained nurse could assist in the final act of assisted death. External review of the process to ensure that regulations are complied with could be carried out by regional review committees along the lines of the Dutch approach. ${ }^{191}$ Such partial de-medicalisation of assisted dying should occur in this jurisdiction to avoid other concerns that remain whilst UK residents must travel abroad for lawful assisted suicide, concerns which are outside of the remit of this paper. ${ }^{192}$ One possible option would be that this form of assisted death becomes part of the palliative care available in the UK, with assisted dying becoming available as a last resort either at a hospice, or, if practical (and affordable), in the person's home.

One of the first questions that would need to be answered to ascertain the feasibility of such an approach is whether non-medic professionals would be willing to be involved in an assisted death. Interestingly, in 2009, the Royal College of Nursing's Council dropped its opposition to assisted dying in favour of a more neutral stance. The vote was taken after a three month consultation of members which received over 1,200 individual responses. 49 per cent of those who responded supported the concept of assisted suicide, whilst 40 per cent did not. ${ }^{193}$ Although this does not necessarily indicate that those nurses supporting assisted suicide would be willing to assist in the final act of suicide, it does at least suggest that a significant number of nurses do not consider the concept of assisted suicide to conflict with their professional ethics. The matter of ethics is also an issue for the professional non-medics who would be involved at other stages in the process. Would clergypersons feel comfortable taking on such a role given that, if they ascertain that an

\footnotetext{
${ }^{191}$ See above, n.128.

192 Such as the fact that law makers in this jurisdiction have no control over the Swiss legal provisions.

193 'RCN neutral on assisted suicide', above, n.173.
} 
individual is competent and this accords with doctor's view, the door is then opened for the individual to go ahead and commit assisted suicide? Could they reconcile their facilitating role with their faith? If indeed there are such faith-based concerns, then the involvement of social workers might be more appropriate. However, if one of the purposes of de-medicalisation is to make the person who will have an assisted death more at ease by being surrounded by familiar people, would it not be necessary to consider the likelihood of the person who wishes to die having an existing professional relationship with a social worker? Or would this familiarity with a non-medic professional be gained during the assisted dying process? It is clear that partial de-medicalisation though the involvement of non-medics in the assisted dying process raises a number of questions that would have to be carefully addressed.

Turning finally to the possibility of de-medicalising assisted death by extending the legitimacy of assisting death where the cause of suffering is non-medical, since the British Social Attitudes Survey indicates that the general public would be less keen to support assisted death in such circumstances, it seems this would be a step too far if any legal reform is to be consistent with the views held by a significant proportion of UK citizens. But the problem here may in fact be that assisted death is so commonly presented within a medicalised framework that the idea that a person should be able to receive assistance to die when suffering is existential receives little attention. If the concept of existential suffering was better defined and more familiar, this might well lead to a more informed public debate on whether assisted death should be de-medicalised in this way. It should give us pause for thought that our preoccupation with the medical model of assisted death means that we are failing to give due regard to the parts of the subjective experience of suffering that are not medical. ${ }^{194}$

${ }^{194}$ See Rurup et al, 2005b: 158 and 163. 
It is patently obvious that the issue of assisted death is not going to go away. ${ }^{195}$ And it is a phenomenon that inevitably possesses significant medical aspects whilst medicine and physicians offer the greatest chance of a "good" death. Given that legal, ethical, political and social discourses continue to reveal a preference for a medicalised model of assisted dying, the pragmatic way forward may well be to continue to present such a model in order to achieve legal reform. That is, even if there is no logical basis for a predominantly medicalised model, it is arguably better to advocate the model that is more likely to be acceptable to the legislature and the public. ${ }^{196}$ An analogy can be drawn here to the way in which abortion was "sold" to the legislature in the 1960s. Whilst the medicalised model of abortion has been heavily critiqued, ${ }^{197}$ at least framing abortion in this way secured a vital change in the law. Unless and until assisted dying in some form is decriminalised, any partially de-medicalised model of assisted dying may be more idealistic than realistic. But it remains the case that, as with abortion, death and assisted death by no means sit exclusively within the domain of medicine. ${ }^{198}$ The examples of the de-medicalisation of assisted death that have formed the focus of this paper serve to emphasise the critical social and emotional aspects of death and the dying process, and to question the appropriateness of physician

\footnotetext{
${ }^{195}$ As expressed by Lord Hope in Purdy, at para 31.

${ }^{196} \mathrm{I}$ am thus suggesting that to succeed in their venture, advocates of legal reform should unite their claims with widely accepted cultural values, the process of "frame alignment", see further Hillyard and Dombrink, 2001: 19-20, 245-248. Notably, according to the DPP's prosecution policy regarding assisted suicide, there is a public interest factor in favour of prosecution where the assistor is a health care professional. However, this should not be taken to suggest that if assisted dying were to be legalised in this jurisdiction, a medical model would not be the favoured approach. This factor was inserted into the final policy because it was identified by 34 per cent of 537 respondents who identified other factors in favour of prosecution that were not in the interim policy. The CPS appears to have included this in the final policy because it was a leading factor given by these respondents, but gives no explanation as to why this should be a factor in favour of prosecution (see above, n.76, para 3.3, 3.5 and 3.7). Besides the ambiguity that I submit this lack of justification presents, assistance from a health care professional was only suggested as a factor favouring prosecution in a total of 184 out of 4,710 total responses to the DPP's consultation and as noted earlier, it is a model involving the assistance of medical professionals that has been the model most consistently presented when legal reform is proposed (see above, nn.33 and 168, 169 and 170).

197 See S Sheldon, 'The Abortion Act 1967: A Critical Perspective' and J Bridgeman, 'A Woman's Right to Choose?' in E Lee (ed), Abortion Law and Politics Today (Macmillan Press, Basingstoke1998) 43 and 76; S Sheldon, Beyond Control: Medical Power and Abortion Law (Pluto Press, London 1997); S Sheldon, 'The Law of Abortion and the Politics of Medicalisation' in J Bridgeman and S Millns (eds), Law and Body Politics: regulating the Female Body (Aldershot, Dartmouth 1995) 105; S Sheldon, 'Subject Only To the Attitude of the Surgeon Concerned: the Judicial Protection of Medical Discretion' (1996) 5 Social \& Legal Studies 95.

${ }^{198}$ See also Hurst and Mauron, 2003: 273.
} 
involvement throughout this process. These matters should not be overlooked or underplayed because of the prominence of the medical model of assisted death. 